\title{
Belge Yönetiminde Yeni Fırsatlar: Dijitalleştirme ve İçerik Yönetimi Uygulamaları
}

\author{
The New Challenges in Records Management: Digitization \\ and Enterprise Content Management Practices
}

Özgür KÜLCÜ*

\begin{abstract}
$\ddot{O z z}$
Bu çalısma özellikle dijitalleştirme ve kurumsal içerik yönetimi uygulamalarının ardından belge yönetimi alanında yeni koşulları tanımlamayı amaçlamaktadır. Günümüzde dijitalleştirme ve içerik yönetimi iç içe gelişmektedir. Dijitalleştirme uygulamaları geleneksel olarak basılı ortamdan elektronik ortama geçişi temsil etse de yapılandırılmamış metin ya da imajların yarı yapılandırılmış ya da yapılandırılmış formlara dönüştürülmesi, tanımlanması ve erişimi faaliyetlerini de kapsamaktadır. Öte yandan kurumsal içerik yönetimi kurumsal bilgi içeriğin tümünün bütünsel olarak idaresini kapsamakta ve doküman yönetimi, belge yönetimi, Web içerik yönetimi ve iş akış yönetimi uygulamalarını içermektedir. Bu kapsamı ile dijitalleştirme ve içerik yönetim faaliyetleri belge yönetimi uygulamalarını yakından etkilemekte, alanın geleceğine yön vermektedir. Çalışma bu çerçevede gelişen süreci ve sonuçlarını değerlendirmektedir.
\end{abstract}

Anahtar sözcükler: Belge yönetimi, Dijitalleştirme, Kurumsal içerik yönetimi

\section{Abstract}

The aim of this study is to investigate the new challenges on records management especially after the emergence and growth of enterprise content management and digitization practices. At the present time digitization and content management are growing together. Traditionally digitization may be described as the studies on transferring print formats to electronic formats; it also includes the transforming of the unstructured text or images to semi-structured or structured forms. On the other hand enterprise content management is one of the terms used in the context of management of whole institutional information content in integrated structure, and includes document management, records management, Web content and workflow management. In this context digitization and enterprise content management are penetrating into records management practice and directed to the evolution of the area. This study evaluates these conditions and their results.

Keywords: Records management, Digitization, Enterprise content management

* Doç. Dr.; Hacettepe Üniversitesi Bilgi ve Belge Yönetimi Bölümü Beytepe 06800-Ankara (kulcu@hacettepe.edu.tr) 


\section{Kurumsal Bilgi Kaynağı Olarak Belgeler ve Belge Yönetiminin Kapsamı}

Yapılandırılmış iş sürecinin parçası olarak üretilen belgeler, kurumsal bilgi ihtiyacını karşılayan, iletişim ve doğrulama faaliyetlerinde yaygın olarak kullanılan dokümanter kaynaklardır (Cisco ve Strong, 1999, s.172). Belgeler diğer dokümanter kaynaklardan farklı olarak parçası olduğu iş sürecine dönük özgün bilgi içerir ve denetimlerde kanıt niteliğine sahiptir. Bu özellikleri ile belgelerin üretimi, düzenlenmesi, dağıtımı, etkin kullanımı ve ayıklanmasına yönelik sistematik yaklaşımlar, belge yönetiminin çalışma alanını oluşturmaktadır (ISO 15489, 2001, s.3; Külcü, 2009, s.265). Kurumsal bilgi içeriğinin önemli bir bölümünü oluşturan belgeler, genellikle şu alanlarda kurumsal faaliyetlere destek olurlar:

$\diamond \quad$ Parçası olduğu işin düzenli, etkin ve yasal çerçevede yürütülmesi,

$\diamond$ Hizmetlerin sürekliğinin ve tutarlılığının sağlanması,

$\diamond$ Paydaşlar ve idari birimlere iş ile ilgili politikaların, kararların, çıktılarının ulaştırılması,

$\diamond$ Denetim faaliyetleri dâhil olmak üzere idari ve yasal gereksinimlere uyumun sağlanması,

$\diamond \quad$ Hukuki itilaflardan korunması

$\diamond \quad$ Mali ve etik sorumlulukların yerine getirilmesi,

$\diamond$ Çalışan, müşteri ve diğer paydaşların hakları ile kurumsal çıkarların korunması,

$\diamond$ Acil durumlara karşı işlerdeki sürekliliğin sağlanması,

$\diamond \quad$ Ortak ve kurumsal hafızanın sürekli kılınması (Sprehe, 2005, s.298).

Giderek basılı ortamın yerini olan elektronik belge yönetimi uygulamaları ile belge yönetimi, basılı üretilmiş belgelerin elektronik kopyaları ile elektronik ortamda üretilmiş belgelerin yönetimini kapsayacak biçimde genişlemektedir. Elektronik belge yönetim sistemleri elektronik dokümanların ve dosyaların üretimi, e-posta yönetimi, tarama ve erişim, iş akışı entegrasyonu, kullanıcı ara yüzleri, mobil çalışma ortamları ve uzaktan erişim vb. alanları kapsamaktadır (Azad, 2008, s. xxii).

Yakın geçmişe kadar kurumsal bilginin tamamının basılı ortamda saklandığını biliyoruz. Dijital depolama ortamlarının kullanılmaya başladığı ilk yıllarda kâğıt ya da mikrofilm olarak basılı kopya saklama geleneği belirli bir süre devam ettirilmiştir. Zamanla en azından güncelliğini yitirmiş belgelerin mikrofilm ya da elektronik kopyalarda saklanması yoluna gidilmiştir. Mikrofilm kullanımının özellikle 1980'li yıllarda zirve yaptığından söz edilmektedir (Cimtech Ltd, 2009, s.10). Ancak arşivlere gönderilmemiş güncel kullanımdaki materyallerin mikrofilm kullanımı pek pratik olamamıştır. 
1980 'li yıllarla birlikte kurumsal yaşamda etkin rol üstlenmeye başlayan bilgisayarlar günümüzde pek çok kurumsal çözümün ana kaynağı olmuşlardır. Yine $80^{\prime}$ lerle yaygın uygulama şansı bulan tarayıcılar ile yüksek çözünürlükte bilgi ve belge kaynaklarının elektronik sistemlerde saklanması ve görüntülenmesi mümkün olabilmiştir. $90^{\prime}$ I yıllarla birlikte yeni kuşak bilgisayar sistemleri ve ofis uygulamaları, elektronik ortamda bilgi ve belge işlemlerini mümkün kılmış ve elektronik doküman yönetimi gelişmiştir. Elektronik doküman yönetim sistemleri bilgi merkezleri ve kütüphanelerde yer alan materyallerin tanımlanması ve erişimine olanak sağladığı gibi bilgi kaynaklarının bütünüyle elektronik sistemlerde üretimi ve yönetimine de olanak sağlamıştır.

Basılı ortamdan söz ettiğimizde örneğin kitaplar için temel erişim sınıflama sistemleri ve konu başlıkları listeleridir. Elektronik ortamda ise tam metin tarama olanağı erişim sistemlerine yeni boyutlar katmıştır (Cimtech Ltd, 2009, s.10).

\section{Belge Yönetiminde Yeni Eğilimler: Bilginin Dijital Ortamda Korunması ve Belgelerin Sürekliliği Yaklaşımının Gelişimi}

Bilgi teknolojilerinin tetiklemesiyle üretilen bilgi miktarının geçmiş yüzyıllarla karşılaştırılmayacak ölçüde artış göstermesine rağmen karmaşıklaşan bilgi yığınlarına erişimin geçmişten daha güç olması ilginç bir ironiyi oluşturmaktadır (Duranti, 2000, s.10; Runardotter, 2007, s.3). Giderek çeşitlenen bilgi kaynakları ve belgesel yapılar sorunları da aynı ölçüde karmaşıklaşmaktadır (Runardotter, 2007, s.3). Dijital ortamda bilgi kaynaklarının yönetiminde yaşanan sıkıntıların belli başlıları arasında; dijital bilginin varlığının sürekliliğinin (continued existence) sağlanması, teknoloji eskimesine karşın erişimin sağlanması, bilgi içeriğinin ve kapsamının özgünlük ve güvenilirliğinin sağlanması (Runardotter, 2007; Ruusalepp, 2005) yer almaktadır. Dijital koruma kapsamında ele alınan ilgili konular üzerine yaklaşımlar geliştirmek bilgi ve belge yönetimi alanında çalışmaların önemli konu başııları arasında yer almaktadır. Dijital koruma, bilgi sistemlerine dönük çalışmaların bir parçası olduğu kadar idari, mali, yasal ve sosyal boyutları ile ele alınması gereken bir konudur (Lavoie ve Dempsey, 2004). Dijital koruma sadece teknik boyutuyla ele alınmamalıdır. Bilgi sistemlerini etkileyen tüm unsurlar dijital koruma kapsamında düşünülmek durumundadır.

Dijital sistemlerde bilgi ve belge kaynaklarının yönetimi ve korunması, geleneksel yaklaşımları çeşitli düzeylerde etkilemektedir. Örneğin belge yönetimi yaklaşımlarının temel aldığı "yaşam döngüsü" (life cycyle) kavramı yerini belgelerin sürekliliği (records continuum) yaklaşımına bırakmaktadır. Bu kapsamda dijital koruma önemli bir belge yönetimi unsuru haline dönüşmektedir. Geleneksel yaşam döngüsü yaklaşımı lineer olarak belgelerin üretimi, düzenlenmesi ve ayıklanması sürecinde belge işlemlerini tanımlarken, belgelerin sürekliliği yaklaşımında belgeler aynı anda birden fazla ortamda ve farklı koşullarda tanılanabilmektedir (McKemmish, 2001). Belgelerin sürekliliği yaklaşımında belgeler sürekli 'olma' halindedir. Yaşam döngüsü yaklaşımında 
birbirinden ayrılmış görevlerle tanımlanmış bilgi sistemi uzmanı, belge ve arşiv idarecileri yeni koşullarda belge koruma sistemi içerisinde iç içe tanımlanmaktadır (Reed, 2000). Belgelerin sürekliliği yaklaşımı dört temel yaklaşımı gerektirmektedir:

$\diamond$ Bilgi sistemleri, belge ve arşiv yönetimi kapsamında tek bir belge kavramının kabul edilmesi.

$\diamond \quad$ Belgelerin niteliğini belirleyen unsurların fiziksel özelliklerinden çok mantıksal (logical) özellikleri olması.

$\diamond$ Kurumsal sosyal ağlar ve iş süreçleri ile belge koruma (recordskeeping) sistemlerinin entegrasyonu.

$\diamond$ Belge ve arşiv yönetimin uzmanlığının kurumsal bilginin organizasyonundan sorumlu kılınması (Upward, 1998; Runardotter, 2007, s.73).

Şekil 1'de kimlik, kimin ne yaptığı (belgelerde tanımlanmaktadır), burada bulunan geçmiş ve kanıt izleri bilginin nasıl depolandığı bilgilerini içermektedir. Kanıt niteliği eylemlerin izlerini; iş sürecinde kullanılabilme, aktivitelerin ürünü olarak belgelerle ilgili kurumsal işleri tanımlamaktadır.

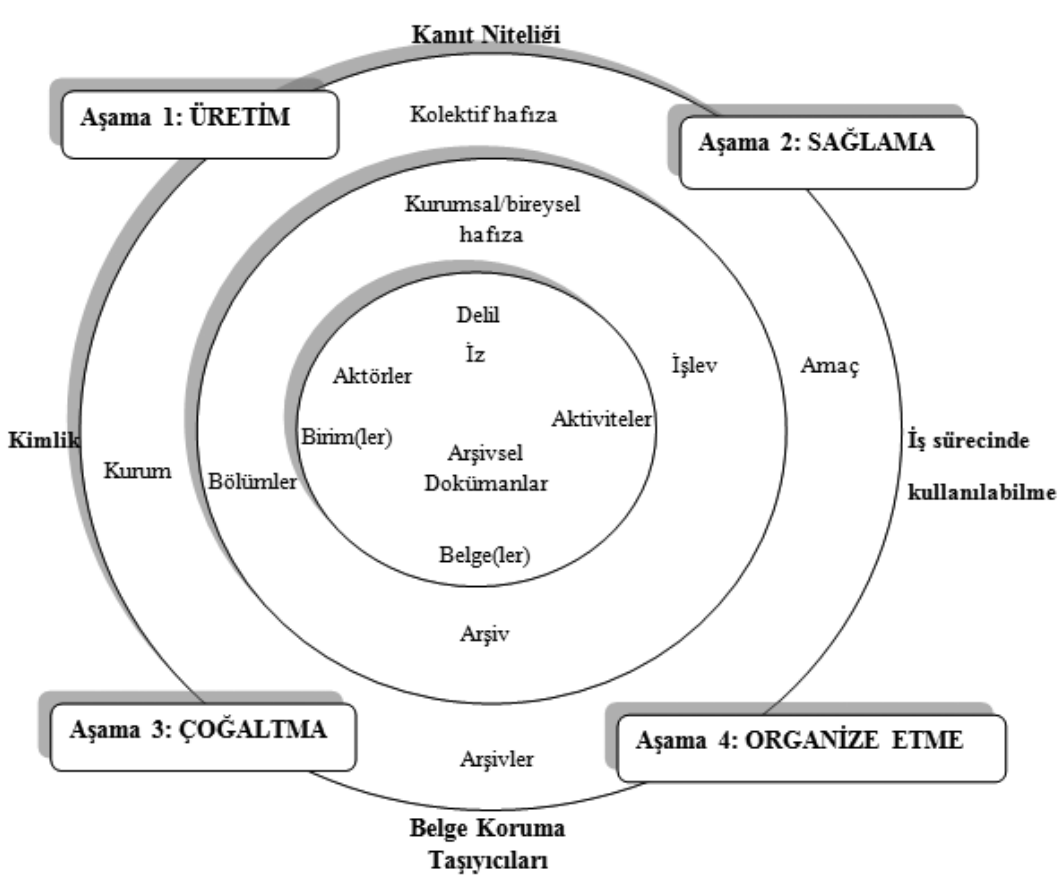

Şekil 1. Belgelerin Sürekliliği Modeli (Upward, 2000, s. 123). 
Belge koruma taşıyıcıları belgelerin depolandığı araçları tanımaktadır. Model içerisinde belgeler aktivitelerin sonunda yer almaktadır. Model içerisinde en aktif çalışmalar üretim aşamasında gerçekleştirilmektedir. Üretilen ve sağlanan belgelerin metadata tanımlamaları bu aşamada gerçekleştirilmektedir. Diğer aşamalarda belgeler, sürecin gerektirdiği ortamlara aktarılmakta ya da arşivlenmektedir (Runardotter, 2007, ss.19-21; Upward, 2004).

Belgelerin sürekliliği modeli aynı zamanda bir sosyal sistemi de tanımlamaktadır. Çalışanları ile birlikte tüm organizasyon, model içerisinde yer almaktadır. Model uygulandığında kurumun kendi dinamikleri sisteme entegre edilebilmektedir (Reed, 2000). Kurum içerisinde üretilen ya da sağlanan belgelerin niteliği ve konumu değişkenlik gösterebilmektedir. Sosyal ağlar yardımıyla belgeye erişim zaman ve mekândan bağımsız hale gelebilmektedir. Belgelerin sürekliliği yaklaşımı kurumsal bilgi ve belge uygulamalarına yeni olanaklar sunmaktadır. Belge ve arşiv yöneticilerinin bu araçların seçimi ve kullanımı üzerine yeni yaklaşımlar geliştirmeleri beklenmektedir. Bu kapsamda dijital belgelerin uzun süre korunması belge ve arşiv uzmanları kadar kurumun ve kurumda görevli personelin ortak konusu olarak algılanmak durumundadır. Örneğin kurumsal değere sahip e-postayı alan ilgili kişinin bunu kurumun ortak hafızası niteliğindeki arşivleme sistemine yükleme sorumluluğu bulunmaktadır (ICA, 2005; Runardotter, 2007, s.74). Yeni koşullarda bilgi ve belge yöneticilerinin görev tanımlarını birbirinden ayırmak giderek güçleşmektedir (International Council on Archives, 2005; McKemmish, 2001; Reed, 2000).

Günümüzde yer olarak arşivlerin önemi giderek azalmaktadır. Artık arşivler her zaman her yerden, farklı sistemler ya da formatlardan erişilebilen ortamlara dönüşmek durumundadır. Arşivleme yerini depolamaya arşiv uygulamaları da dijital koruma uygulamalarına dönüşmeye başlamıştır. Bu kapsamda politika üretemeyen, gerekli altyapı yatırımlarını gerçekleştiremeyen kurumların kurumsal işlerinde ciddi risklerle karşı karşıya kalmaları yanında kurumsal geçmişlerini yitirme tehlikesi içinde olacaklardır (Runardotter, 2007, ss.76-78).

\section{Dijital Ortamda Belgelere Dönük Tehditler ve Geliştirilen Projeler / Standartlar}

Günümüzde belgeleri tehdit eden en ciddi sorunun, doğal afetler ya da yangın tehlikesinden çok değişen dosya formatları olduğuna değinilmektedir (Goldstein, 2004). Bu çerçevede belgeler dijital ortama aktarılırken ve elektronik ortamda belge işlemlerine dönük programlar geliştirilirken aşağıdaki unsurların öncelikle ele alınması gerekli görülmektedir.

$\diamond$ Kanıt (evidence): Elektronik ortamda belgelerin kanıt niteliğini sürdürebilmeleri için dijital imza ve çoklu imza özeliklerinin tanımlanması. 
$\diamond$ Güvenilirlik (reliability): Güvenilirlik ilgili olay için belgenin geçerliliğini tanımlamaktadır. Örneğin belgenin içeriğine duyulan güvenin sağlanması (Duranti, 2000).

$\diamond$ Özgünlük (authenticity): Belgelerin özgünlüğü elektronik enformasyonla yakından bağlantılıdır. Elektronik ortamda özgünlüğü geçerli kılmak için çaba harcanması gerekmektedir(Duranti, 2001, s.271).

$\diamond$ Sorumluluk (accountability): Belgelerin kurumsal sorumlulukların denetlenmesinde kullanılan araçlar olarak tanımlanması (Bearman, 1994; Thomassen, 2001, s.373).

$\diamond$ Okunabilirlik ve Elde Edilebilirlik (readility and availability): Elektronik ortamda farklı formatlardaki kaynaklara erişimin sağlanması. Özellikle güncel kullanımı olmayan formatlar için araçları bulmak ciddi sorun teşkil edebilmektedir. Bu sorun güncel kullanımda olan uygulamalar için sürücü (driver) bulmakta bile yaşanabilirken geçmişe dönük sorunun boyutları artabilmektedir (Asproth, 2005).

Yukarıda dile getirilen koşulları daha iyi tanımlayabilmek, yaşanan sorunlara çözüm arayabilmek ve uygulamaları mümkün kılmak için bir dizi proje başlatılmıştır. Bu projelere kısaca aşağıda tanıtılmaktadır.

InterPARES (International Research on Permanent Authentic Records in Electronic Systems): Dijital ortamda belgelerin özgünlüğü, güvenilirliği ve uzun süre korunmasına dönük yaklaşımlar ve uygulama modelleri geliştirmeyi hedefleyen, alanında en uzun soluklu projesidir (Asproth, 2005, s.33). 1999 yılından bu yana devam etmekte olan Proje içerisinde elde edilen veriler, çeşitli standartlar ve kaynak dokümanların hazırlanmasına referans olmuştur (The InterPARES Project, 2009).

CEDARS (Curl Exemplars in Dijital ARchiveS); projesinin ana hedefi dijital koruma üzerine en iyi uygulamaları tanımlayan stratejik, metodolojik ve uygulamalı rehber sağlamak olmuştur. Proje 2002 yılında sonuçlandırılmıştır (CEDARS, 2006).

CAMiLEON (Creatieve Archiving at Michigan \& Leeds: Emulating the Old on The New): Michigan ve Leeds Üniversiteleri tarafından yürütülen proje belgelerin uzun süre alıkonması, korunması ve eski sistemlerde tanımlanmış dijital kayıtların erişimine dönük teknolojilerin araştırılması üzerine odaklanmıştır (CAMiLEON, 2003).

NEDLIB (Networked European Deposit Library): Avrupa ulusal kütüphanelerinin birlikte yürüttüğü bir projedir. Ağlaşmış Avrupa derleme kütüphanelerinin temel alt yapısını oluşturmayı hedefleyen bir projedir (Nedlib, 2009).

MINERVA (Ministerial NEtwoRk for Valorising Activities in digitisation): Web Koruma Projesi ilgili konuda temel kaynakları derleyerek daha geniş programları 
başlatmak için oluşturulmuştur. Farklı uzmanlık alanlarındaki takımlar kataloglama, kamu hizmetleri ve teknolojik olanaklar konularında çalışmalar yürütmüş, elektronik ortamda materyallerin seçimi, derlenmesi, kataloglanması, erişimi ve korunması üzerine araştırmalar yapmışlardır (MINERVA, 2009).

PANDORA (Preserving and Accessing Networked Documentary Resources of Australia): Avustralya ulusal koruma programına seçilen çevrimiçi Avustralya yayınlarının sağlanması, arşivlenmesi ve uzun süre erişimi üzerine prosedürlerin geliştirilmesi amacıyla başlatılmıştır (PANDORA, 2008).

VERS (Victorian Electronic Records Strategy); elektronik belgelerin sağlanması, yönetimi ve korunması üzerine çözümler üretmektedir. VERS elektronik belgelerin güvenilirliği ve özgün olarak arşivlenmesi üzerine standartlar rehberleri eğitim materyalleri, danışmanlık ve ilgili alanda proje uygulamaları için bir çerçeve oluşturmaktadır (VERS, 2009).

ERA (The Electronic Records Archives): ABD Ulusal Arşivi tarafından elektronik formatların herhangi birinde kaydedilmiş belgelerin sistematik, kapsamlı ve dinamik biçimce korunmasını sağlamaya dönük stratejikyaklaşımla geliştirmeyi hedeflemektedir (Asproth, 2005, ss.33-34; ERA, 2009).

Yukarıda yer alan projelerin çıktıları günümüzde elektronik ortamda belgelerin özgünlüğü ve güvenilirliğini değerlendirmeye ya da geliştirmeye dönük bir dizi eylem planı ortaya koymuştur. Değinilen projelerin bir kısmı doğrudan dijitalleştirme uygulamalarının gerçekleştirilmesine dönük geliştirilmiş ve sonuçlarıyla dijitalleştirme ve dijital içeriğin yönetimine dönük uygulama örneği niteliğindedir. Kuramsal ayağı ağır basan InterPARES, CEDARS, MINERVA ve ERA ise uygulamalara yön verecek politika ve stratejilerin geliştirilmesine odaklanmış, diğer proje ve uygulamalara referans oluşturacak çıktılara sahiptir. Bu çerçevede dijitalleştirme ve dijital içerik yönetime dönük zengin bir bilgi birikiminden söz etmek mümkündür.

Aşağıda yer alan standartlar da ilgili konuda yol gösterici nitelikte bilgiler içermektedir:

$\checkmark \quad$ ISO 15489-1 Bilgi ve Dokümantasyon - Belge Yönetimi için standart: Bu standart belge yönetimi uygulamalarının değerlendirilmesi üzerine bir kontrol listesi oluşturmaktadır

$\diamond$ ISO 15489-2: Sistem yönetimi ve proje yönetimi çalışmalarının bir parçası olarak ISO 15489-1 standardının öngördüğü belge sistemlerinin geliştirilmesi ve uygulanması üzerine (DIRS: Developing and Implementing Records Systems) bir rehberdir.

$\checkmark$ TS 13298 Bilgi ve Dokümantasyon - Elektronik Belge Yönetimi:Türkiye'de elektronik sistemlerde belge yönetimi programlarının yapılandırılması üzerine sağladığı 
kuramsal içerik yanında, dijitalleştirme uygulamalarına dönük, master ve farklı kullanım formatlarının tanımlanması ile dijital uygulamalarda göz önünde bulundurulacak koşulları da belirleyen önemli bilgiler içermektedir (Türk Standartlar Enstitüsü, 2007).

$\diamond \operatorname{ISAD}(G):$ General Standard Archival Description

$\checkmark$ ISAAR(CPF) International Standard Archival Authority Record for Corporate Bodies, Persons, and Families

$\diamond \quad$ Açık Arşivler Bilgi Sistemi için Referans Modeli-The Reference Model for an Open Archival Information System (OAIS): OAIS dijital bilginin uzun süre korumak ve erişimini sağlamak için arşiv sistemleri için kavramsal bir çerçeve oluşturmaktadır (Reference Model for an Open Archival Information System (OAIS, 2002).

Yine pek çok uzman XML'i format probleminin çözümüne katkı sağlayan bir standart olarak görmektedir. Ancak XML'in var olan ve gelecekte kullanılabilecek tüm bilgi kayıt türleri ile uyumlu olmamayabileceği ifade edilmektedir (Asproth, 2005, s.34).

\section{Dijitalleştirme ve Dijital Koruma Gerekçeleri}

Dijitalleştirme genel olarak elektronik sistemlerce algılanamayan yapılandırılmamış formdaki bilginin elektronik ortamca algılanabilecek yapılandırılmış forma çevrilmesi uygulamalarını tanımlamak için kullanılmaktadır. Dijitalleştirme uygulamalarının önemi bir yönünü dijital koruma oluşturmaktadır. Terminolojide genellikle dijital koruma ve dijital arşivleme birbirlerinin yerine kullanılabilmektedir. Elektronik ortamlarda üretilen belgeler yanında basılı ortamda olup elektronik sistemlerde de görünürlükleri sağlanan belgeler dijital korumanın kapsamını daha da genişlemektedir (Rieger, 2008). Bu çerçevede dijital koruma, basılı ortamda tek kopya olarak üretilen belgelerin yedeklenmesi yanında çoklu erişiminin sağlanmasını da hedeflemektedir.

Genel olarak dijitalleştirme ve dijital koruma uygulamalarında aşağıdaki koşulların göz önüne alınarak gerçekleştirilmesi gerekmektedir (Cornell University Library 2009; Rieger, 2008, s.3):

1. Tüm içeriğin dijitalleştirilmesi gerekli mi? Hangi kaynakların korunması gerektiği üzerine seçim işlemleri nasıl uygulanabilir? Geniş ölçekli bir araştırmaya göre kütüphane kaynaklarının \%20'si toplam ödünç verilen materyallerin \%80'ini oluşturmaktadır. Uzun yıllara dayanan iki farklı kütüphaneye ilişkin İngilizce kitapların ödünç verme istatistiklerine dönük OCLC verilerine göre; kaynakların \%10'u toplam ödünç verilen materyallerin \%90'ını oluşturmaktadır. Diğer yayınların \%75 ile \%90'ı ise son 17 yıldır hiç ödünç alınmamıştır. Dijitalleştirme üzerine çalışmalar zaman, emek ve oldukça yüksek maliyet gerektiren çabalardır. Bunun için dijitalleştirme çalışmalarında gerekli ön analizlerin yapılması son derece önemli görülmektedir (Dempsey, 2006; Rieger, 2008, s.3). 
2. Basılıkopyasıpekkullanılmayan materyallereelektronikerişimyenitalepleryaratabilir mi? Orta ve büyük ölçekli bilgi merkezleri genellikle kapsamlı bir koleksiyona sahiptir. Ancak kullanıcılar genelde erişim için karmaşık yöntemler kullanmamaktadır. Öte yandan tüm kopyaları ödünç verilmiş ya da yanlış yerleştirilmiş materyallere erişim mümkün değildir. Dijital ortam bu problemleri ortadan kaldıracağı için erişimin ve kullanımın etkileşeceğini söylemek mümkündür (Dempsey, 2006).

3. Dijitalleştirme özel ya da nadir eserleri hangi yönleri ile etkilemektedir? Nadir kitaplar, el yazmaları, fotoğraflar, efemeralar, personel ya da profesyonel yazışmalar, haritalar, güzel sanatlar çalışmaları, görsel işitsel materyaller özel ihtimam gerektirebilmektedir. Gerek materyalin yapısı, gerek yaşı ve özgünlüğü gösterilecek özenin nedenleri arasında olabilmektedir. Bu materyallerin dijitalleştirilmesi genellikle daha güç ve maliyetli görülmektedir. Özel önem gerektiren materyallerin dijitalleştirilmesinde daha profesyonel yaklaşımların uygulanması, özgünlüğünü ve değerini korumalarını sağlayacak koşulların belirlenmesi son derece önemlidir.

\section{Dijitalleştirme Uygulamaları}

Birleşmiş Milletler Arşivler ve Belge Yönetimi Birimi (Archives and Records Management Section, ARMS) tarafından 2006 yılında yayımlanan Belge Dijitalleştirme Rehberi'ne göre dijitalleştirme, kâğıt belge, fotoğraf, grafik malzemeler gibi fiziksel/analog materyallerin elektronik ortama ya da elektronik ortamda depolanan imajlara dönüştürtmesi işlemi (United Nations, 2006) olarak tanımlanmaktadır.

Dijitalleştirme uygulamalarının temel olarak üç nedenden ötürü yapıldığı dile getirilmektedir:

$\diamond \quad$ Kağıt belge ve depolama maliyetinin azaltılması: Seçilmiş dijital belgelerin dijital ortamda depolanması kağıt ve depolama alanı maliyetinde azaltma yarattığı gibi hayati belgelerin (vital records) korunması açısından önemlidir.

$\diamond$ Kurumsal Iç̧erik Yönetimi (Enterprise Content Management) Çözümlerinin Uygulanması: Belgelerin dijitalleştirilmesi ve elektronik belgelerin kullanımının artması, kurumsal süreçlerde farklı bilgi kaynaklarının paylaşımını kolaylaştıracağı için kurumsal içerik yönetimi faaliyetleri etkin biçimde gerçekleştirilebilmektedir.

$\diamond$ Arşivsel Koruma: Dijitalleştirme orijinal kopyaların kullanımını azaltacağı için arşiv belgelerlinin uzun süre korunmasında önemli avantajlar sağlayacağı gibi çoklu kullanım olanakları da yaratabilmektedir (United Nations, 2006).

Dijitalleştirme kurumsal bilgi ve belge yönetimi programlarının bir parçası olarak uygulanmak durumundadır. Kurumların halihazırda dosyalama, bilgi güvenliği ve belge saklama vb. planlarının olması ilgili alanda dijitalleştirme uygulamalarını kolaylaştıracaktır. 
Bilgi ve belge kaynaklarının kanıt niteliğinin sürdürülebilmesi için elektronik kopyaların özgün (authentic), bütün (complete) ve erişilebilir (accessible) olması gerekir. Bu kavramlar tablo 1'de gösterildiği gibi tanımlanmaktadır (United Nations, 2006).

Tablo I. Bilgi ve Belge Kaynaklarının Kanıt Niteliğini Sürdürmesinde Önemli Olan Kavramlar

\begin{tabular}{ll}
\hline Kavram & Tanım \\
\hline Özgün & $\begin{array}{l}\text { Belgeler ve gerekli bilgi kaynakları tanımlanmış bir sistem içerisinde, gerekli yetkilendir- } \\
\text { meler ve kayıt süreçleri çerçevesinde üretilmelidir. }\end{array}$ \\
Bütün & $\begin{array}{l}\text { Dijital kayıt, içerikle ilgili basılı formda bulunan unsurlara ilişkin hiçbir kayıp olmadan } \\
\text { tüm fiziksel ve entelektüel unsurları yansıtmalıdır. }\end{array}$ \\
Erişilebilir & $\begin{array}{l}\text { Gereksinim duyulduğu sürece erişim hakkı bulunan kişilerce erişilebilir, taranabilir } \\
\text { ve okunabilir olmalıdır. }\end{array}$ \\
\hline
\end{tabular}

Öte yandan hassas ya da gizlilik değeri olan belgelerin dijitalleştirilmesi dikkatli gerçekleştirilmelidir. Bu tür belgeler için uygun metadata, güvenlik ve erişim unsurları mutlaka tanımlanmalıdır. Bu tür belgelere sadece gerekli yetkilere sahip personelin tanımlanmış sınırlamalarla erişimi sağlanmalıdır. Gizlilik değeri taşıyan belgelerin dijitalleştirmesi ve tanımlanması işlemleri diğer belgelerden ayrı tutulmalıdır.

\section{Dijitalleştirme Sürecinde Metadata Alanlarının Tanımlanması}

Belgelerin erişimini etkinleştirmek için ilgili kaynakların önceden tanımlanmış taksonomiler ya da dosya planları çerçevesinde düzenlenmesi ve tanımlanması gerekmektedir. Taksonomiler fonksiyonları temel alarak belgelerin tanımlanması ve organizasyonu için bir yapı ortaya koyarken; metadata, tarih, orijin ve doküman türü gibi belgeler hakkındaki daha ayrıntılı bilgileri içermektedir. Geleneksel olarak dosya planı ya da belge sınıflama planı belgelerin düzenlenmesine yardımcı olacak kategorileri tanımak için kullanılmaktadır. Dijitalleştirilen belgelerin kurumsal dosya planı ya da belgelerin sınıflandırılmasına dönük hazırlanan planlar çerçevesinde yerleştirilmeleri gerekmektedir. Belgeler orijinal fiziksel düzenlemelerine (arrangement; fiziksel yerleşimle ilgili) göre taranmalıdır. Elektronik belgelerin (dijitalleştirilen ya da epostalar gibi dijital üretilen -born digital-) etkin yönetimleri için tek biçim tanımlama (unique identifier) ya da metadata unsurlarına gereksinim vardır. Metadata unsurları ne kadar ayrıntılı tanımlanırsa belgelere erişim o derece etkinleşecektir.

Tablo II'de sunulan belgelere yönelik metadata unsurlarına dönük liste, Uluslararası Belge Yönetimi Standardı ISO 15489 ve Dublin Core Metadata Unsurları göz önüne alınarak geliştirilmiştir (Dublin Core Metadata Initiative, 2008; ISO 15489-1, 2001; United Nations Archives and Records Management Section (ARMS), 2004). 
Tablo II. Belgelere Yönelik Metadata Unsurları

\begin{tabular}{ll}
\hline Metadata Unsurları & Gereklilik \\
\hline Tanımlayıcı (identifier) kod & Zorunlu \\
Başlık & Zorunlu \\
Konu & Opsiyonel \\
Tanımlama & Opsiyonel \\
Üretici & Zorunlu \\
Zaman & Zorunlu \\
Adresler & E-postalar için zorunlu \\
Belge türü & Elde edilebildiğinde zorunlu \\
İlişki & Elde edilebildiğinde zorunlu \\
Fonksiyon & Opsiyonel ancak tavsiye ediliyor \\
Seri/Fon (aggregation) & Zorunlu \\
Dil & Zorunlu \\
Yerleşim & Opsiyonel \\
Güvenlik ve Erişim & Zorunlu \\
Düzenleme & Zorunlu \\
Format & Zorunlu \\
Koruma & Opsiyonel \\
\hline
\end{tabular}

Ayrıca ülkemizde TS ISO 13298 çerçevesinde özelikle kurumsal belge niteliğindeki kaynakların daha ayrıntılı tanımlanmasına dönük metadata unsurları aşağıdaki gibi tanımlanmıştır. Geliştirilen şablon çok kapsamlı olduğundan metadata elemanlarına ilişkin temel başlıkların verilmesiyle yetinilecektir (Kandur, 2007).

$\diamond$ Dosya tasnif planı

$\diamond$ Birimler

$\diamond$ Seri Tanımları

$\diamond \quad$ Klasör Dosya Tanımları

$\diamond$ Saklama Planı

$\diamond$ Tasfiye İşlem Tanımları

$\diamond$ Belge. $\diamond$ Güvenlik Seviyesi

$\diamond$ Kullanıcı Rolleri

$\diamond$ Kullanıcı Profilleri

$\diamond$ Kullanıcı Grupları

$\diamond$ Belge Bileşenleri

$\diamond$ Sistem Kullanımı 
Belge kaynaklarının yapısı ve bu kaynaklardan beklentiler, belgelerin tanımlanması ve gereli metedata alanlarının oluşturulmasında belirleyici bir öneme sahiptir. Genel nitelikli Dublin Core standartlarından ISO 13298 ya da EAD (Encoded Archival Description, 2002) gibi belgelere özel daha ayrıntılı standartlara kadar kullanılacak metadata modeline karar vermek için beklenti analizlerinin yapılması önemli görülmektedir.

\section{Dijital Ortamda Bilginin Kullanımı: Yapılandırılmış ve Yapılandırılmamış Dijital Dokümanlar}

Dijitalleştirme uygulamalarında göz önüne alınması gereken önemli bir konu da bilginin dijital ortama nasıl aktarılacağı ve bu ortamda bilginin kullanım koşullarıdır. Basılı ortamdaki herhangi bir bilginin farklı elektronik ortamlarca okunabilir yapılandırılmış dokümanlara dönüştürülmesi dijitalleştirme uygulamalarının önemli bir aşamasını oluşturmaktadır. Bu kapsamda doküman kavramı geniş anlamıyla okunabilir formattaki bilgi olarak tanımlanmaktadır. Basılı belgelerin dışında elektronik ortamdaki dokümanlar ise yapılandırılmış elektronik dokümanlar ve imaj tabanlı elektronik dokümanlar olmak üzere ikiye ayrılmaktadır (Breuel, 2005, s.4).

Yapılandırılmış elektronik doküman örnekleri arasında HTML, XHTML, XML, LanTeX ve Microsoft Word uygulamaları yer almaktadır. Bu uygulamalar ofis araçları, Web tarayıcılar, sunum paketleri, çevrimiçi form işleme sistemleri ve benzeri yazılım paketleri aracılığıca kullanılmaktadır. Yapılandırımış formda veriler elektronik ortamda kodlanmış şekilde genellikle başlık, sayfa numarası, yazar, versiyon vb. bilgiler ile metin, font, sitil, boyut, renk, konum vb. işaretleri tanımlanmış biçimde depolanmaktadır. Yine yapılandırılmış elektronik belgeler, çizim ve fotoğrafik imajların dijital kodlarını da içerebilmektedir. Yapılandırılmış elektronikdokümanlarıngenellikleiyi tanımlanmışsözdizimi ve semantiğe sahip olması, üzerine yürütülecek elektronik işlemleri ve farklı sistemlere aktarılmaları ya da dönüştürülmelerini kolaylaştırmaktadır. Ancak yapılandırılmış dokümanların en önemli dezavantajı temsil kapasitelerinin sınırlılığında görülmektedir. Örneğin XHTML formatı elektronik yayıncılık için iyi tanımlanmış yapılandırılmış doküman formatıdır. Ancak matematiksel bilgiler ya da imajların gösterimi için söz dizim ve semantik eksiklikleri söz konusudur. Bunun için MathML ve SVG gibi ek standartlar olmadan XHTML formatı vektör grafikleri ve matematiksel formülleri gösterememektedir. Öte yandan imaj tabanlı dokümanlar kayıtlı bilgileri piksel piksel gösterirler. Okuma düzeni ya da imaj parçalarının mantıksal işlevleri hakkında çok az ya da hiç veri içermezler. Metne erişimi kolaylaştırmaya yönelik bazı metinsel metadata verileri eklense de imaj bir bütün olarak tek bir resim dosyası olarak algılanır. İmaj tabanlı dokümanlar basılı belgelerin taranmasıyla üretildiği gibi yazıcı sürücüleri ya da Windows sistemleri tarafından da üretilebilirler. İmaj tabanlı dokümanlara örnek olarak TIFF grafikleri, DjVu anahtar tabanlı imaj sıkıştırma formatları, "ink" in çeşitli formasyonlardaki örnekleri, bilgisayar kalemleri ile çizimler verilebilir. PDF formatı her ne kadar imaj tabanlı olsa da giderek daha fazla yapılandırılmış doküman özelliği taşıdığından söz edilmektedir (Breuel, 2005, s.4). 




Şekil 2. Dokümanların elektronik ortamda sunum türleri

İmaj tabanlı dokümanlar piksellerin sıkıştıııması ile gösterildiklerinde söz dizim ya da semantik bilgisi ya yoktur ya da çok az sahiptir, ancak imaj bütünlüğünü tam olarak yansıtırlar. Örneğin bir sayfanın TIFF imajı metin, grafik, matematiksel rotasyon, kimyasal yapı, çizimler ve fotoğrafları gösterebilir. Gösterimdeki problemler ancak çözünürlük ve renk derinliği ile ilgilidir. Yapılandırılmış dokümanlarla imaj tabanlı dokümanlar arasındaki ayrım bazen yukarıdaki kadar kesin olmayabilir. Genellikle Şekil 2'de olduğu gibi formatlar ve kapasiteler arasında bir hiyerarşi söz konusudur. Dokümanın sunumunda ne kadar yapılandırıımış öğe söz konusuysa o kadar kapasiteyi desteklediği söylenebilir. Örneğin basit bir Bitmap formatı çevrimiçi yayımı destekleyebilir, ancak ötesinde herhangi bir olanak sunamaz. DjVu, imaj tabanlı PDF dosyaları, SVG, postcriptler çoklu çözünürlüklerde kullanımı ve çeşitli boyutlarda sıkıştırmayı mümkün kılarlar. Font tabanlı PDF dokümanları, HTML ve RTF dokümanları doküman içi taramaya, açıklama eklemeye, küçük düzeltmelere bazen yeniden akışa (farklı çıktı boyutlarının adaptasyonu) izin verirler. Microsoft Word, HTML ve LaTeX gibi mantıksal şablon bilgileri ile doküman formatları ile düzeltme işlemleri ve farklı ortamlarda yapılandırma mümkün olabilmektedir. XML ya da diğer bütünüyle semantik işaretlenmiş doküman türleri ile dokümanların otomatik olarak manipülasyonu ve yeni hedeflerde yapılandırılması gerçekleştirilmektedir (rapor yazımı, posta birleşmeleri). Günümüzde dokümanların çok büyük bir kısmı, gerek e-posta sistemleri ve Web araçları, gerek kelime işlemciler 
(Microsoft Word, OpenOffice vb.) gerekse işaretleme dillerinde (LaTeX, SGML, DocBook) bilgisayarlarda ya da sunucularda saklanmaktadır. Doküman üzerinde işlemler büyük oranda İnternet üzerinden (haberler, makaleler, bilimsel yayınlar, idari ve yasal düzenlemeler, iş formları, ürün broşürleri vb.) gerçekleştirilmektedir. Yayım ve değişim işlemlerinde ise yaygın olarak grup ağları (groupware) ve belge depoları kadar e-posta sistemlerinden yararlanılmaktadır (Breuel, 2005, ss.1-5).

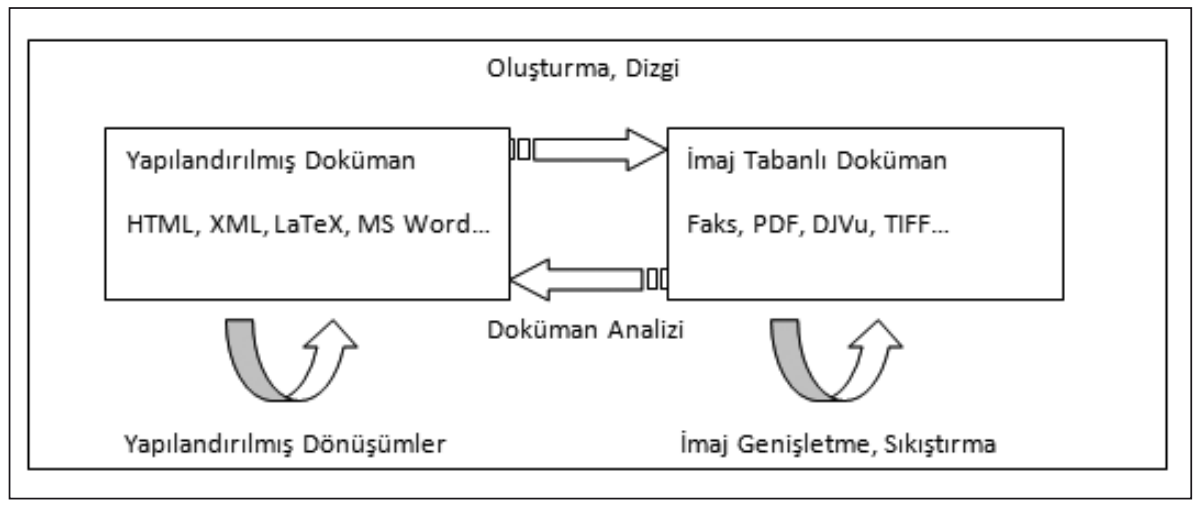

Şekil 3. İmaj tabanlı dokümanlarla yapılandırılmış dokümanlar arasındaki ilişki (Breuel, 2005, s.2).

Şekil 3'de imaj tabanlı dokümanlarla yapılandırılmış dokümanlar arasındaki ilişki görülmektedir. Şekil 3'de de görüldüğü gibi dizgi (typesetting) çalışmaları ile yapılandırılmış doküman formatından imajlar elde edilebilmektedir. Doküman analizi imaj tabanlı dokümanlardan yapılandırımış dokümanların oluşturulmasına dönük faaliyetleri içermektedir. Bu döngüde yapılandırılmış dokümanlar ve imaj tabanlı nesneler birbirlerine dönüşebildikleri görülmektedir.

Geleneksel olarak doküman işleme uygulamaları, basılı belgelerin elektronik ortamlara dönüştürülmesi şeklinde yapılmakta, genellikle metin tabanlı belgeler taranarak elde edilen imaj dokümanlar, doküman şablon analizi (layout analysis) ve optik karakter tanıma (optical character recognation, OCR) olanakları ile işlenmekte böylece basılı belgelerin kelime işlemci gibi elektronik araçlarca algılanabilir elektronik formlara dönüştürülmesini sağlamaktadır. Ancak bu uygulamalarda belgelerin basılı özelliklerinin tümünün elektronik ortama aktarılmasının gerçekleşemediği dile getirilmektedir. Günümüzde çok büyük miktarda kitap ya da doküman metin tabanlı olarak yayımlanmakta ya da saklanmaktadır. Özellikle yayıncılar denetimsiz kopyalama ve yayımlama endişelerinden ötürü kitapların elektronik kopyalarını basmakta tereddüt edebilmektedir. Yine senet hükmünde olan yazışmalar, idari, malî ve yasal uygulamalarla ilgili belge işlemleri, çeşitli endişeler, mahremiyet ya da kullanıcı ilgisizliği yüzünden 
büyük ölçüde basılı formda yürütülmektedir. Öte yandan dokümanların elektronik ortamda yüksek kalitede depolanabilmesi, ağ teknolojileri ve mobil cihazlarla zaman ve mekân sınırlaması olmadan erişilebilmesi imkânlarına rağmen pek çok arşiv yüzyılların geleneği, yarattığı güven ortamı ve yasal yükümlülüklerden ötürü dokümanlarını basılı formatlarda saklamayı sürdürmekte ve bu koşullarda basılı belgelerin üretim artışı devam etmektedir (Infotivity Technologies, 2009; West, 2002, s.5).

Ancak uzmanlar yakın gelecekte kâğıt tabanlı belgelerin Web, çevrimiçi formlar, çevrimiçi yayıncılık ve elle kullanılabilir elektronik okuyucuların yaygınlaşması ile tarih olacağını dile getirmektedirler. Son dönemlerdeki çalışmaların özellikle semantik ve dokümanların yüksek düzeyde sunumu üzerine standartların geliştirilmesi, $\mathrm{XML}$, DocBook, MathML ve SVG standartların kullanım alanının genişletilmesi üzerine odaklandığına değinilmektedir (Breuel, 2005, ss.3-5; Sellen, 2001, s.3).

Dijitalleştirme uygulamalarını vazgeçilmez bir parçası olan doküman analizinin önemli bir aşaması, imaj tabanlı dokümanların yapılandırılmış dokümanlara dönüştürülmesidir. Örneğin OCR sistemleri günümüzde TIFF formatındaki işlenmemiş Bitmap dosyalarını mantıksal işaretlenmiş metin dosyalarına çevirmektedir. Bu aşamada şu adımlar söz konusudur; (Bkz. Şekil 4)

$\diamond \quad$ Illk aşamada doküman imajı içerisindeki metinler diğer öğelerden ayrılmaktadır. Bu operasyonun çıktıları DjVu ya da Digipaper gibi yüksek sıkıştırmalı doküman formatlarında gösterilirler.

$\diamond$ İmaj ve karakterlerin koleksiyonu ardından geometrik analiz, karakter tanıma ve dil modellemesinin konusudur. Bu işlemlerin fiziksel çıktısı PDF dokümanı ya da HTML dosyası olur ancak kalitesi orijinal doküman kadar yüksek değildir.

$\diamond$ Dokümanların yüksek kalitede yapılandırılmış formatlara dönüştürülebilmesi için, girdi metninin farklı parçalarını tanımlayacak mantıksal şablon analizini takip eden fiziksel şablon analizi yapılmalıdır. Örneğin bölüm başlıkları, başlıklar, sayfa başlığı dipnotlar, alt yazılar, metin akışı vb. tanımlanması.

$\diamond$ Metin analizi, içerik analizi ve bilgi çıkarma teknikleri kullanılarak ek semantik bilgiler de alınabilir (Breuel, 2005, ss.6-7). 


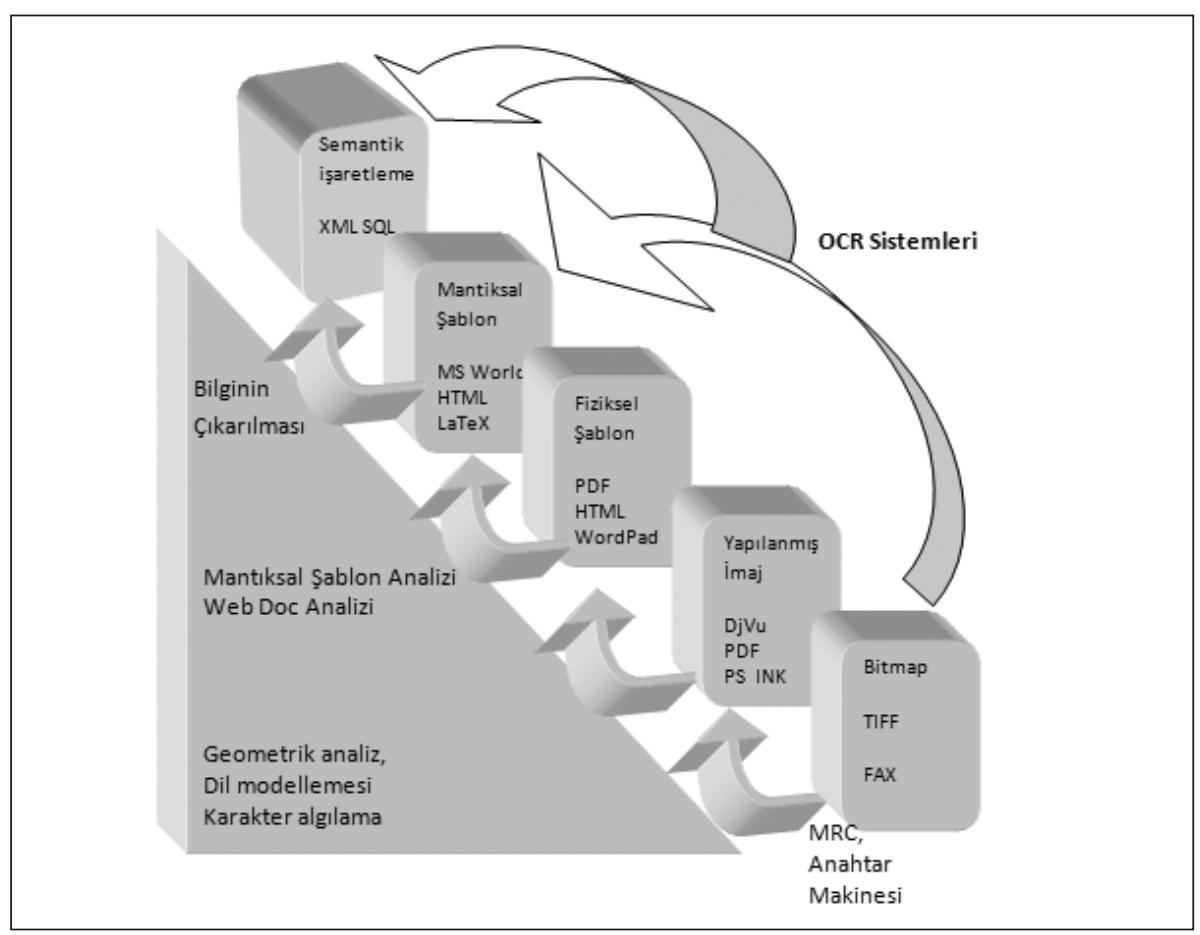

Şekil 4. Doküman analiz işlemlerinin çeşitli aşamaları: imaj tabanlı gösterimden içeriğin ve şablonun yüksek düzeyde gösterimi

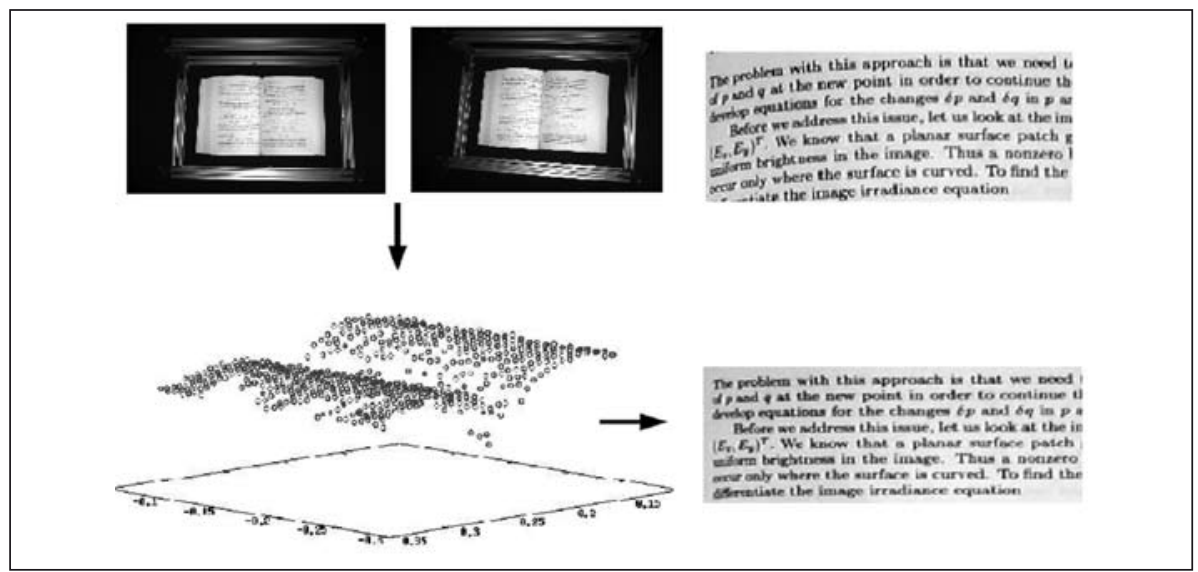

Şekil 5. Stereo görüntüleme tekniği kullanılarak kamera tabanlı doküman elde etme 
Stereo görüntüleme tekniği kullanılarak kamera tabanlı doküman elde etmek için dokümanın iki farklı açıdan fotoğrafı çekilmektedir (Bkz. Şekil 5). Ardından stereo görüntüleme ve interpolasyon teknikleri uygulanarak üç boyutlu yüzey yeniden yapılandırılmaktadır. Bu teknik özellikle bozuk ve sorunlu yüzeylerde etkili bir yöntem olarak kullanılmaktadır (Breuel, 2005, s.12).

Dijitalleştirme uygulamalarındaki tartışma konularından biri de elektronik ortamda dokümanların hangi formatlarda saklanacağına karar vermektir. Bölüm içerisinde tartışıldığı gibi yapılandırılmış ve yapılandırılmamış e-dokümanların kullanım alanlarına göre çeşitli avantajları olabilmektedir (Bkz. Tablo III).

Tablo III. Yapılandırılmış ve yapılandırılmamış elektronik dokümanların kullanım alanlarına göre avantajları (Breuel, 2005, s.19).

\begin{tabular}{|c|c|}
\hline Yapılandırılmış Sunum & İmaj Tabanlı Sunum \\
\hline \multicolumn{2}{|l|}{ İmaj Tabanlı Dokümanların Avantajları } \\
\hline Kullanıcı sunum şeklini belirleyemez & $\begin{array}{l}\text { Kullanıcı istediği biçimde dokümanı } \\
\text { görüntüleyebilir }\end{array}$ \\
\hline $\begin{array}{l}\text { İçerik işaretleme nasıl tanımlanmışsa ancak o } \\
\text { şekilde görüntülenebilir }\end{array}$ & Herhangi bir içerikte gösterilebilir \\
\hline Farklı formatlara çevirmek güçtür & Farklı formatlara çevirmek kolaydır \\
\hline $\begin{array}{l}\text { Doğru işaretleme yaratmak yoğun bir çaba } \\
\text { gerektirir }\end{array}$ & Ekranda doğru göründüğü anda yapılabilir \\
\hline $\begin{array}{l}\text { Tasarımda gizli metadata güvenlik ve } \\
\text { mahremiyet unsurları içerir }\end{array}$ & Görünen veriler olan tüm verilerdir \\
\hline
\end{tabular}

\begin{tabular}{l|l}
\hline \multicolumn{2}{l}{ Yapılandırılmış Dokümanların Avantajları } \\
\hline Sunumu değiştirmek stil dosyalarında kolaydır & Sunum değiştirmek zordur \\
\hline Kompleks taramaya olanak tanır & $\begin{array}{l}\text { Veri bağlantıları kurmaya dönük henüz bir araç } \\
\text { geliştirilmemiştir. }\end{array}$ \\
\hline
\end{tabular}

Şekil 6'da dijital ortamda doküman formatları arasındaki geçiş ve ilgili dokümanlara erişimine dönük döngüyü yansıtılmaktadır (Breuel, 2005, s.19). Gelecekte imaj tabanlı dokümanların yapılandırılmış formatlarda gösteriminin artması ile imaj tabanlı doküman kullanımının daha da yaygınlaşabileceği üzerine durulmaktadır.

Günümüzde kurumsal belge yönetimi hızla elektronik ortama kaymaktadır. Bu çerçevede hâlihazırda elektronik ortamda üretilen ve kullanılan kaynaklar yanında basılı kaynakların dijitalleştirilmesi belge yönetimi çalışmalarının önemli bir yönünü oluşturmaktadır. Çalışma içerisinde değinildiği gibi dijitalleştirme çok yönlü çalışmaları gerektirmektedir. Dijitalleştirilecek içeriğe karar verme süreci ile başlayan, dijitalleştirme ortamı ve formatı ile devam eden dijital içeriğin tanımlanması, aktarımı, güvenlik, erişim 
ve yetkilendirme koşullarının belirlenmesini içerisine alan bu sürecin tanımlanması ve etkin yönetimi gerekmektedir. Ardından içerik yönetim süreçleri devreye girmektedir. Çalışmanın ilerleyen bölümlerinde içerik yönetimi ve kurumsal içerik yönetimi üzerinde durulmaktadır.

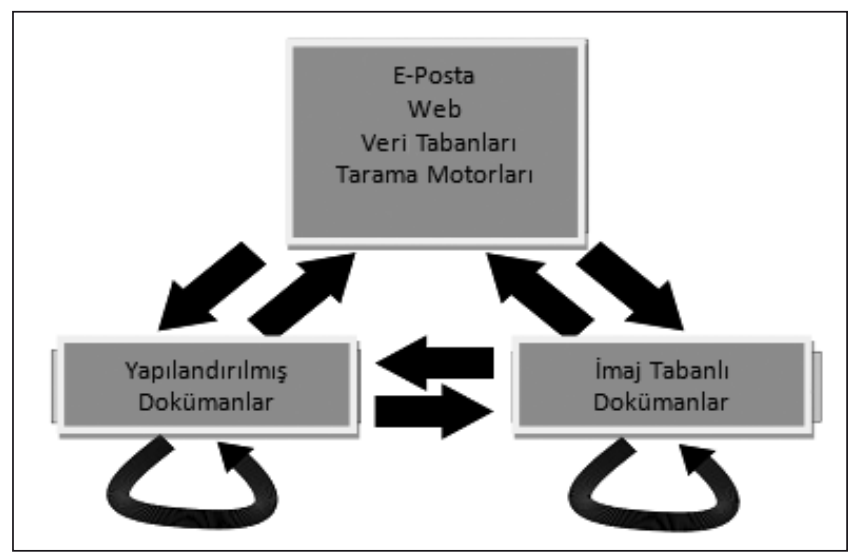

Şekil 6. İmaj tabanlı dokümanlar ve yapılandırılmış dokümanlar arasındaki ilişki

\section{Kurumsal İçerik Yönetimi: Tarihsel Gelişimi}

90'ların ortalarından itibaren kurumlar, ortak yürütülen faaliyetler için elektronik sistemlere yönelmiştir. Kullanıcılar için elektronik dosyalardaki bilgilere erişim ile birlikte paylaşım da ön plana çıkmıştır. Kurumsal bilgi içeriğinin yer aldığı anlık mesajlaşma, programlama (scheduling) çevrimiçi toplantı, içerik paylaşımı, grup yönetimi, form yönetimi, bilgi yönetimi, uygulama (application) paylaşımı, whiteboarding, iş süreç yönetimi bu kapsamda değerlendirilmektedir. Bu uygulamaların bir kısmı yapılandırılmamış özel işlemleri (ad hoc processs) bir kısmı da yüksek miktardaki tanımlanmış ve yapılandırılmış işlemleri kapsamaktadır. Ortak çalışmaları destekleyen en basit ve esnek çözüm e-posta sistemleri olmuştur. 1990'larda e-postaların öncüsü 'Lotus Notes' ile tanınan ortak çalışma yazılım uygulamaları (groupware) gelişmiş, ardından benzer pek çok uygulama ortaya çıkmıştır. Ortak yazılım uygulamaları kurumsal bilgi ve iletişim teknolojilerine dönük alt yapının gelişimine de önemli katkılarda bulunmuştur. 1980 'lerin sonu ve 1990'ların başı iş akış yönetimi yazılımları, kurumların iş süreçlerinin yeniden tanımlanması, otomasyon, değişim yönetimi ve kıyaslama (benchmarking) gibi kavramların kurumsal çerçevede yoğun olarak tartışıldığı dönemler olmuştur (Cimtech Ltd, 2009, ss.10-11). 


\section{Elektronik Yayıncılık ve İçerik Yönetimi}

Kelime işlemcilerin ofislerde kullanımı ile birlikte e-yayıncılık yazılımları da görülmeye başlamış, yaygınlaşması ise ilgili alanda standartların gelişimi ile paralel olmuştur. Başlangıçta belli başlı tüm uygulama örnekleri kendi standartları ile ortaya çıkmışıı. Örneğin IBM'in 1969'da geliştirdiği Genelleştirilmiş İşaretleme Dili (Generalized Markup Language) daha sonra ISO 8879 kodu ile uluslararası bir standarda dönüşmüş ve Standart Genelleştirilmiş Iş̧aretleme Dili (Standart Generalized Markup Language-SGML) kısaltmasıyla tanınmıştır. Zamanla SGML büyük ve karmaşık dokümanların karşılıklı değişiminde olmazsa olmaz bir standarda dönüşmüştür. Internet ve 'webin gelişimiyle yeni bir standart olarak SGML üzerinde Hipermetin İşaretleme Dili (HyperText Markup Language-HTML) geliştirilmiştir. Basit yapısı ile HTML, pek çok programcıya Web ile çalışan programları ve araçları kolayca kurma olanağı yaratmıştır. HTML unsurlarının çoğu genellenebilir ve tanımlanabilir olmasına karşın belirli klişelerin kullanımını gerektirmektedir. HTML genişletilebilir olmadığından belirli doküman türlerinin uzantısı olarak kullanılamamaktadır. Bu çerçevede özellikle Web arama motoru işletmecilerinin öncülüğünde HTML uygulamalarının geliştirilmesi için çalışmalar başlatılmış, World Wide Web Konsorsiyumunun öncülüğünde (W3C) XML geliştirilmiştir. XML farklı bilgisayar sistemleri arasında veri akışına olanak sağlamaktadır. E-yayıncılık elektronik doküman yönetiminden çok, içerik yönetim sistemleri üzerine özel talepler yaratmıştır. İçerik yönetimi yapılandırılmış dokümanlardan çok içerik ya da gerekli bilgi parçacığı üzerinde yönetim stratejileri geliştirmeyi gerektirmektedir. İçerik yönetim sistemleri, kurumlara içerik parçalarından faydalanma, tekrar kullanma ve yayımlama olanağı sağlamaktadır. Bir içerik yönetimi çözümü, içeriği sunum formatından ya da sağlama mekanizmasından ayrı olabilmektedir. Bir belge ya da doküman yönetim sisteminde genelde dokümanı nasıl görüntüleyeceğimize ilişkin seçim şansımız yoktur. Geleneksel olarak herhangi bir imajı, belirli bir imaj görüntüleme programı ya da imajın üretildiği programı kullanarak görüntüleyebiliriz. Iç̧erik yönetim sistemi ile içerik SGML ya da XML ile tanımlandığında içeriğin hangi araçlarla görüntülenebileceği de belirlenebilmektedir (Bosak, 1999, ss.1-3; Cimtech Ltd, 2009, s.12; Herrera-Viedma, 2003, ss. 234-238).

Böylece içerik yönetim sistemleri içeriği veri tabanındaki veri gibi tanımlayabilmektedir. Içerik orijinal formatta tutulurken çeşitli yollarla kullanım olanağı sağlanabilmektedir. Bir içerik yönetim sistemi yarı yapılandııımış içeriğin kurum tarafından faydalanılabilmesi için tekrar kullanılabilir bilgi kaynağına dönüştürürken, veri tabanlarının yapılandııımış bilgiye dönük yaklaşımına benzer bir yol izlemektedir.

İçerik yönetim sistemlerinin desteklediği özelliklerden bir tanesi de birleştirici (assembly) yönüdür. İçerik yönetim sistemleri dokümanları içerik unsurları ile birlikte ekranda ya da basılı ortamda sunabilmektedir. Uzun yıllar içerik yönetimi büyük şirketler ya da yayıncılar tarafından özel bir pazar olarak görülmüştür. İnternetin yaygınlaşması ve webin içerik yönetimi pazarına doğru genişlemesi alanın gelişimine önemli katkılar 
sağlamıştır. Web 1.0 Uygulamaları ve Web İçerik Yönetimi ardından elektronik belge yönetimi programlarının ortaya çıkışı KIY kavramının bugün aldığı boyutlarda önemli bir yere sahiptir (Bkz. Şekil 7) (Cimtech Ltd, 2009, s.13; Munkvold, 2006, s.70).

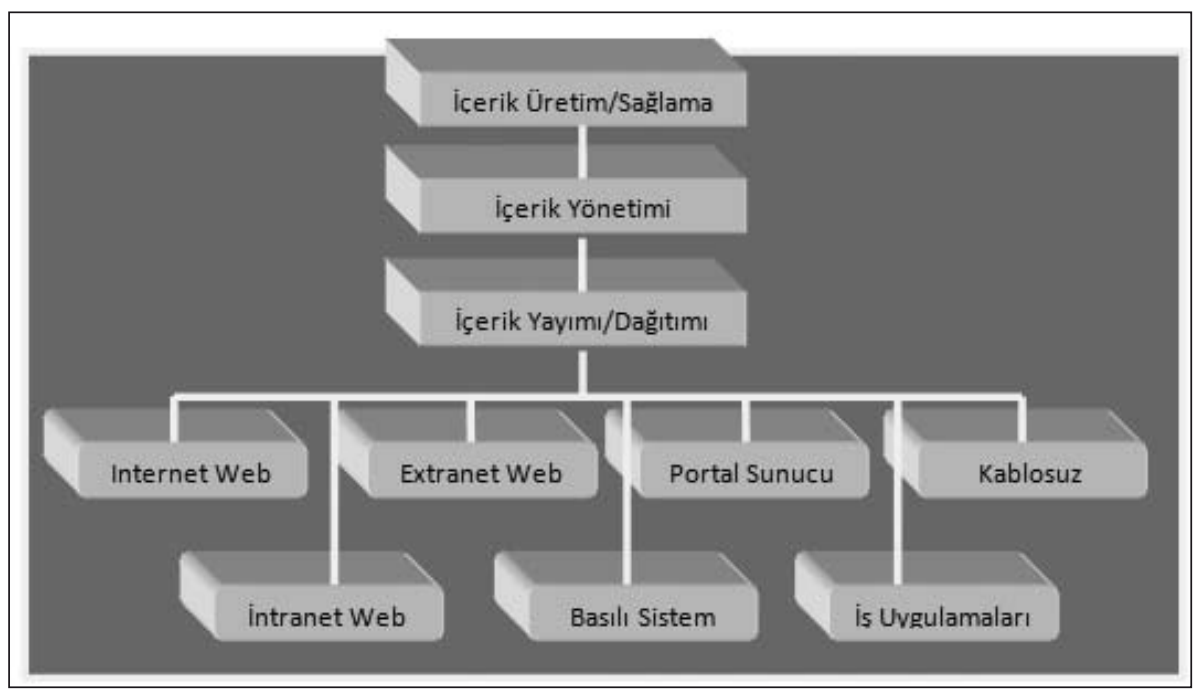

Şekil 7. İçerik Yönetimi Sistem Olanakları (Cimtech Ltd, 2009, s.12).

\section{Kurumsal İçerik Yönetimi (KiY) Kapsamı ve Unsurları}

KIY, yapılandırılmış (structured), yarı yapılandırılmış (semi structured) ve yapılandırılmamış (unstructured) kurumsal bilginin, içeriğe gömülmüş yazılım kodlarının ve metadata unsurlarının yönetimi, var olan içeriğin yayınlanması, depolanması, dağıtımı ve kurumsal amaçlarla kullanımı üzerine çözümleri tanımlamaktadır. Kavram kurum içi (in house) bilgi sistemleri ile Web içeriğinin yönetimi üzerine çabaların öncülüğünde gelişmiştir (Päivärinta, 2005, s.1). Şekil 8'de KIY yaklaşımının gelişmesine öncülük eden yapılandırılmış ve yapılandırılmamış içeriğin bütünleştirilmesi döngüsünü yansıtılmaktadır. Şekilde görüldüğü gibi iş süreçlerinin parçası olarak üretilen ya da elde elden veri, içerik yönetim sistemine koruma programı ile dâhil edilmekte, önceden tanımlanmış erişim, depolama, yönetim ve sağlama süreçleri ile bir döngüye dönüşmektedir.

KIY uygulamalarının gelişiminde Bilgi ve İmaj Yönetim Derneği (The Association for Information and Image Management, AIIM, 2009)'nin yürüttüğü kuramsal ve uygulamalı çalışmalarının önemli bir yeri vardır. AlIM KiY'i, kurumsal işlemlerle ilgili dokümanları ya da içeriği sağlama (capture), yönetme, depolama, koruma ve hizmete sunma ile ilgili teknolojilerin bütünleşmesi olarak tanımlamaktadır. Günümüzde yaklaşım ve 
çözümler "Web içerik yönetiminin" ötesine geçmiş, tüm ön uç (front end) uygulamaları ve araçlarının arka uç (back end) doküman/dosya yönetim sistemleri ve veri tabanları ile yakınsamaların (convergence) yönetimine doğru evrimselleşmiştir. İ̧erik yapılandırması ve karşıııkı değişim standartlarının özellikle XML'in gelişimi, Web sayfaları, veri tabanları ve uygulamalar ile çoklu erişim araçlarının bütünleştirilmesi üzerine ortaya çıkan teknolojik yaklaşımlar, kurumsal ölçekte yakınmamaları kolaylaştırmıştır (Morrison, Morrison ve Keys, 2002, s. 81). Giderek KiY kavramı teknolojik çözümlerin ötesine geçmiş, kurumların yaşam döngüsünde (Bkz. Şekil 8) bilgi varlıklarını (information asset) yönetmeleri için gerekli stratejiler, araçlar, işlemler ve yetenekleri kapsayacak biçimde evrimleşmiştir (Smith ve McKeen, 2003, s.647).

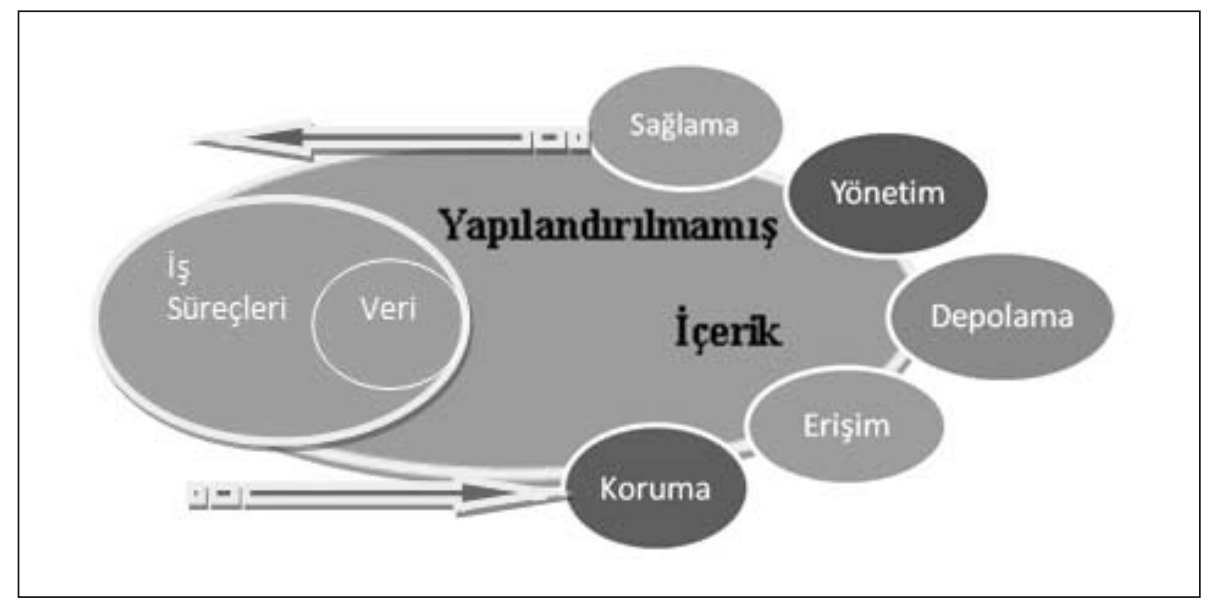

Şekil 8. Yapılandırılmış ve yapılandırımamış bilginin entegrasyonu (AIIM International, 2003; Kampffmeyer, 2006, s.3).

İçerik yönetimi, var olan içerik türleri ve yapıları ile gerekli olduğu sürece belirli içeriğin nasıl yönetileceğine ilişkin bilginin bütünleştirilmesine dayandırılmaktadır (Päivärinta ve Munkvold, 2005, s.1). Etkili içerik yönetimi, farklı ortamlardaki heterojen içsel ve dışsal kaynaklardan gerekli verilerin sağlanması ve dosya formatının dönüştürülerek bütünleşik bir ürünün oluşturulmasını gerektirmektedir. İ̧erik yönetimi kapsamında kontrollü düzenleme (editing), gözden geçirme (review), onaylama ve çoklu kanaldan bilgilendirme, dağıtım, yayım ve içeriğin güncellenmesi, bu uygulamaların teknik yönlerinin tanımlanması, içeriğin işlenmesi ve yayımı için gerekli iç akışının tanımlanması (her düzeyde tanımlanmış politikaları içermelidir) gerekmektedir. Yine yedekleme koşullarının tanımlanması, sürüm kontrolü ve revizyon geçmişi yönetimini içeren kontrollü depolama ortamlarının yaratılması, içerik yönetimi uygulamalarının kapsamındadır. Depolamada içerik düzeylerinin çeşitli aşamalarda tanımlanması 
gerekmektedir. İçerik yönetimi kapsamında bilgi kaynaklarının e-arşivlerde uzun vadede saklama koşullarının tanımlanması, ayıklama ve imha uygulamaları ile format değişimi ele alınması gereken diğer konular arasındadır (Päivärinta ve Munkvold, 2005, s.1).

KiY uygulamalarında elektronik içeriğin metadata tanımlamaları son derece önemli bir yer tutmaktadır. Metadata unsurları erişimi ve tekrar kullanımı etkinleştirmek için içerik elemanları ve yapılandırılması ile kaynağın üretimi, sahipliği, muhtemel kullanım özellikleri hakkında bilgi sağlamalıdır. Ancak farklı formatlarda hazırlanan içerik kaynaklarının ortak bir metadata sistemi içerisinde tanımlanması üzerine ciddi çabaların harcanması gerekmektedir. Ortak sınıflama (corporate taxonomy) tüm içeriğin mantıksal ya da kavramsal olarak bütünleştirilmesi anlamına gelmektedir. Kullanıcıların, belirli bir mantık silsilesi içerisinde hazırlanmış içeriğe erişmesi ya da bu içerik içerisinde gezinmesi için uygun koşullar yaratılmak durumundadır. Örneğin paylaşımdaki koleksiyonlar/depolar tanımlanmalı ve kurumsal postallar içerisinde içeriğe erişmek için sanal semantik ağlar oluşturulmalıdır (Päivärinta ve Munkvold, 2005, s.1).

Özellikle bilgi teknolojilerinin olanaklı kıldığı aşağıdaki alt yapı koşulları KiY uygulamaları için önemli görülmektedir. Kurumsal içerik yaşam döngüsü çerçevesinde tanımlanmak ve bütünleştirilmek durumundadır (üretim/sağlama, depolama, işleme, iş akışı, yayın ve heterojen içeriğin uzun süre arşivlenmesi ve işlemlerin entegrasyonu). Bu uygulamalar kişisel e-postaların yönetiminden işe yönelik kritik içeriğin tanımlanmasına kadar pek çok bileşeni içermektedir. Içeriği yönetmek için "ön uç” içerik ürünü ve tarama çözümleri ile bütünleşik kullanıcı odaklı, sezgisel ara yüzler tasarlanmak durumundadır. Yüksek düzeyde içeriğin yer aldığı çevrede içerik sağlama cihazları, ağlar ve depolama araçlarının sürekli gözden geçirilmesi, kapasite gereksinimlerinin yeterliliğinin tespiti gereklidir. Bağımsız içerik uygulama formatlarına dönük XML gibi teknolojik yenilikler, satıcıların belirlediği belirli içerik formatları ve yapılarına bağımlılığı azaltmakta, kurumlar arasında içeriğin paylaşımını kolaylaştırmaktadır. Öte yandan bilgi güvenliği sorunları ciddi bir endişe kaynağıdır. Örneğin kullanım anahtarı, elektronik imza, dijital hakların yönetimi, içerik şifreleme ve güvenli veri ağları için teknolojik entegrasyonların içerik yönetim çözümleri ile ele alınması gerekmektedir (Päivärinta ve Munkvold, 2005, s.6; Scott, Globe ve Schiffner, 2004, ss. 37-52).

Şekil 9 içerik yönetimi uygulamalarının temel unsurlarına yer vermektedir. Şekil 9'da görüldüğü gibi içerik yönetimi çalışmaları, farklı içerik sunucular arasında işbirliği ile elde edilen içeriğin, Web içerik yönetimi, belge yönetimi, iş akışı ve iş süreç yönetimi ve doküman yönetimi çalışmalarının bütünleştirilmesi ile hizmete sunulmasını kapsamaktadır. 


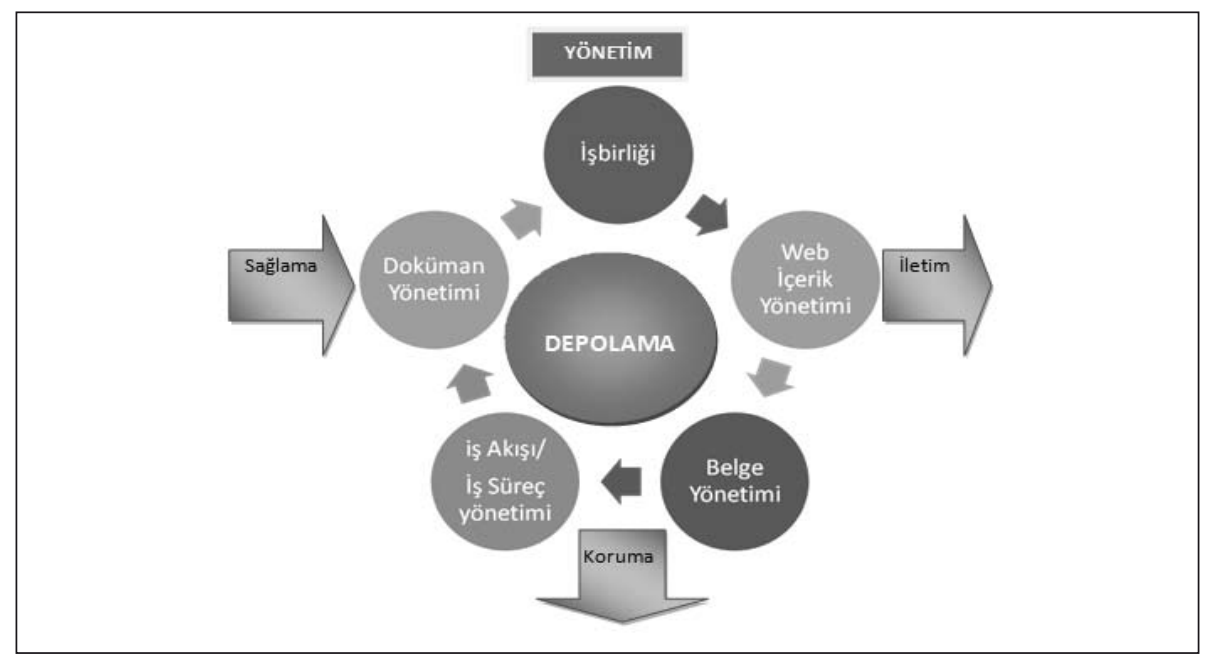

Şekil 9. KiY'nin 5 Temel Unsuru (Kampffmeyer, 2006, s.15).

\section{İçerik Yönetimi Uygulamaların Yapılandırılması}

KIYY, bilgi içeren tüm dijital dokümanlar, veri, form, rapor ve Web sayfalarını içeren, kurumların bilgi kaynaklarını yönetmeleri için gerekli stratejiler, araçlar, işlemler ve yetenekleri kapsayan bilgi sistemlerinin yükselen bir alanını oluşturmaktadır (Nordheim, 2006, s.648; Smith ve Mckeen, 2003). Kurumsal bilgi yönetimi uygulamaları KiY ile yakından ilişkilidir. KIY'in bilgi yönetiminin bir alt alanı olduğuna dair literatürde çalışmalar bulunmaktadır (Scott, Globe ve Schiffner, 2004). Öte yandan içerik denildiğinde bunun yapılandırılmış bir bilgi kaynağı olması da gerekmemektedir. Örneğin çeşitli türde çoklu ortam içeriği, herhangi bir kurumun iş sürecinde anlam taşıyorsa içerik yönetimi kapsamında değerlendirilebilmektedir (Nordheim, 2006, s.649). Günümüzde KIY sistemleri doküman, resim, ses ya da video dosyalarını işleyebilmektedir. Kurumlarda uygulanacak içerik yönetimi programlarının, kurumun tabi olduğu yasal ve idari düzenlemelerle uyumlu tasarlanması gerekmektedir (Ewers, 2007,s.1). Belge/doküman yönetiminden KIY uygulamalarına geçişle birlikte, basılı ve elektronik sistemlerde ortamı ne olursa olsun tüm bilgi içeriğinin bütünleştirilerek sunumu ön plana çıkmıştır (Ewers, 2007,s.7).

İçerik yönetimi, idari politikalar, standartlar, düzenlemeler, programlar, kurumsal idari yapı ve işleyiş̧e ilişkin koşullarla yakından ilişkilidir. İçerik yönetimi, kurumlarda metin ya da çoklu ortamdaki içeriğin teknik ve sosyal yönleri göz önüne alınarak idaresi üzerine odaklanmaktadır. Dört temel bileşeni söz konusudur.

1. Teknik Yönü: Yeni geliştirilen donanım/yazılım uygulamaları ve içeriğin yönetimine ilişkin standartlar. 
2. Kullanıc Yönü: Kullanıcı için var olan ya da amaçlananların gereksinimlerin değerlendirilmesi, kişisel kullanım yöntemlerinin belirlenmesi.

3. İşlem Yönü: İş koşullarını ve işi destekleyen çözümlerin analizi ve/veya geliştirilmesi.

4. Iç̧erik Yönü: Farklı içeriğin tanımlanması, kombinasyonu, modellenmesi ve özel uygulama alanları (Tyrväinen, Salminen ve Päivärinta, 2002).

Bu çerçevede KiY sistemleri geliştirilirken göz önünde bulundurulması gereken unsurlar ise şunlardır:

\begin{tabular}{|c|c|}
\hline Mimari & $\begin{array}{l}\text { Sistem dışındaki verilerin sağlanması ürün ya da entegrasyon çözümlere } \\
\text { dönük alt yapı koşulları }\end{array}$ \\
\hline Bütünleşme & Farklı ortamlardaki içeriğin bütünleşmesi \\
\hline $\begin{array}{l}\text { Birlikte Bulunma } \\
\text { (Coexistence) }\end{array}$ & Var olan uygulamalar ile yeni ürünlerin birlikte ve karşılıklı çalışma koşulları \\
\hline Kullanılabilirlik & Ürün hakkında kullanıcı deneyimleri \\
\hline Verigöçü & $\begin{array}{l}\text { Var olan çözümlerden yeni çözüme bilginin aktarımı ya da dönüştürülmesi } \\
\text { (Nordheim, 2006, s.657). }\end{array}$ \\
\hline
\end{tabular}

Bu çerçevede temel bir KIY sistemi yazılım mimarisinde yer alması beklenen unsurlar:

$\diamond$ İşbirliği yönetimi yazılımı,

$\diamond$ Web yayıncılığı yazılımı,

$\diamond$ Tarama ve içerik sınıflama (taxonomy) yazılımı,

$\diamond$ i̇ş akışı,

$\diamond$ Sunucu yazılımıdır (Nordheim, 2006, s.656).

Genel olarak bir KIY programının sahip olması beklenen temel unsurlar ise;

$\diamond$ Süreçlerde içeriğin sağlanmasından güvenliğine tüm aşamaların tanımlanması,

$\diamond$ Doküman ve metin veri tabanları,

$\diamond$ İçeriğin özelleştirilmesi, uluslararası hale getirilmesi ya da yerelleştirilmesi,

$\diamond$ Kaynakların çok kanallı yayımı ve doküman formatları,

$\diamond \quad$ Çok dilli ya da çok kültürlü içeriğin yönetimi,

$\diamond$ İçerik yapısı ile ilgili bilgiye erişim,

$\diamond$ İçerik konfigürasyonu,

$\diamond \quad$ KIY, XML gibi özel veri formatların kullanımı,

$\diamond$ Kullanıcı modelleri / profillerine dayanarak içerik havuzundan konfigürasyonun otomatik oluşturulması, 
$\diamond$ Organizasyon yapısı içerisinde metadata kullanımı,

$\diamond$ içerik yaşam döngüsü modelleri,

$\diamond$ İçerik yönetimi üzerine bilgi güvenliği,

$\diamond$ Dijital hakların yönetimi,

$\diamond$ Bilgi sistemlerinin planlanması içinde içerik yönetimi sorunları,

$\diamond$ Organizasyon kapsamında alan çalışmaları,

$\diamond$ KiY uygulamasının yaralarının değerlendirilmesi,

$\diamond$ E-iş, e-devlet, e-eğitim, e-kültür vb. uygulama alanlarında KiY çözümleridir (Tyrväinen, Salminen ve Päivärinta, 2002).

Bu kapsamda KiY uygulamalarında sisteme veri girişinden erişimine değin temel süreçler:

Sağlama (capture): Elektronik ya da analog bilgiyi üretme /sağlama, hazırlama ve işlemeye yönelik işlevler ve unsurlarının kombinasyonu. Dijital görüntüleme, metin tanımlama ve indeksleme teknolojilerini de içermektedir.

Indeksleme: Indeksleme işlemlerinde dokümanın daha sonra erişimi için metadata alanlarının tamamının doldurulması oldukça önemlidir. İndeksleme anahtar kelime ya da tam metin olarak yapılabilir.

Koruma:Uzun dönemli koruma, güvenlik ve yetkilendirme ile yedekleme koşullarının tanımlanması gerekir.

Erişim: Sistem içerisinde yer alan bilginin gereksinim duyulduğu anda erişiminin mümkün kılınması gerekir (Ewers, 2007,s.7).

KiY sistemlerinde yönetim fonksiyonları doküman yönetimi, ortak sistemleri, Web içerik yönetimi, belge yönetimi ve iş akışı/iş süreç yönetimi gibi unsurların bileşiminden oluşmaktadır. Uzun süre kullanım değeri taşıyan içeriğin erişimi ve uygun koşullarda depolanması sağlanmak durumundadır. Şekil 10, bir KiY uygulamasında içerik sağlama fonksiyonlarını göstermektedir. 


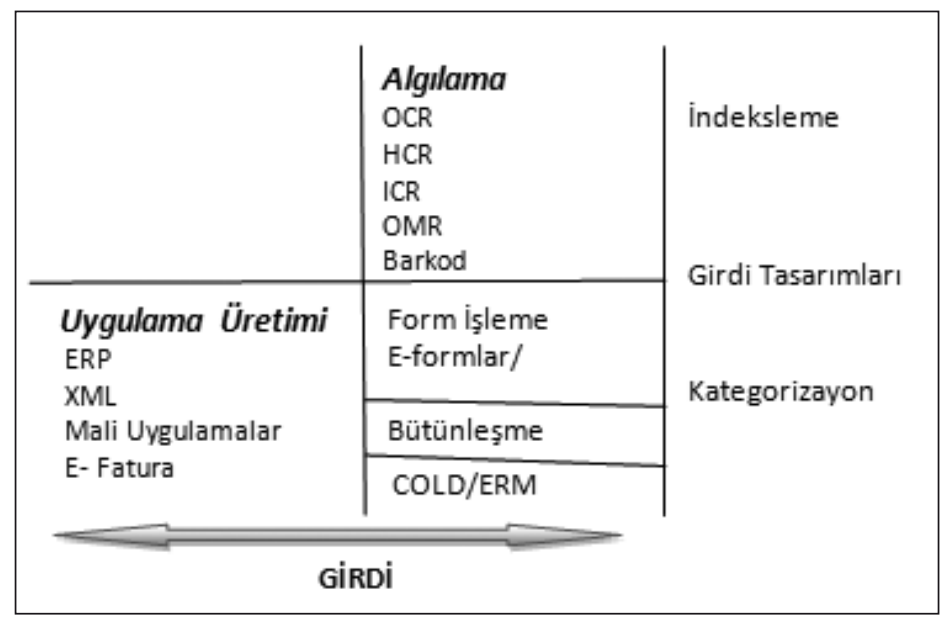

Şekil 10. KiY İçerisinde İçerik Sağlama (Kampffmeyer, 2006, s.29).

Şekil 10'da görüldüğü gibi, KiY içerisine veriler insan üretimi ya da doğrudan uygulamalardan elde edilmektedir. Sistemin verileri algılayabilmesi için kullanılan araçlardan geçen verilere dönük girdi aşamasında yapılan bir diğer işlem tanımlamadır. Şekil 11 ise, KIY sistemine girişi yapılan verilerin kullanımını göstermektedir.

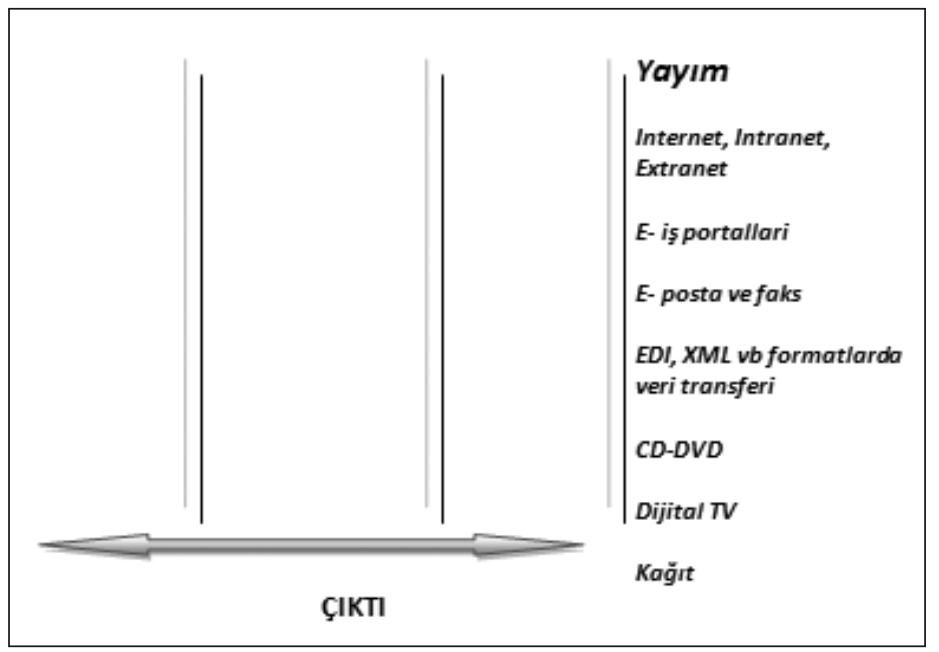

Şekil 11. KiY Kaynaklarına Erişim (Cimtech Ltd, 2009; Kampffmeyer, 2006, s.65). 
Şekil 11'de görüldüğü gibi, sistemdeki verilerin erişimi ve yayımına dönük ara yüzlerin tasarımı, verinin sunulacağı formatların belirlemesi, erişim ve kısıtlamalar ile diğer güvenlik koşullarının tanımlanmasının ardından verinin hangi ortamda yayımlanacağına karar verme KIY sistemleri içerisinde çıktı işlemleri olarak tanımlanmaktadır.

Kurumlar içerik, doküman ve belge yönetimi gereksinimi ile tüm bu unsurlarının ortak kullanımına duyulan ihtiyaç KIY uygulamalarının tetikleyici gücü durumundandır. Günümüzde KIY uygulamalarının ve ilgili konuda geliştirilen programların aşağıdaki alanlarda yoğunlaştığı görülmektedir.

1. Nokta çözümleri: Özellikle küçük ya da orta büyüklükteki kurumların özel bir konudaki sorunlarına dönük geliştirilen çözümler: Genel olarak arşiv çözümleri, elektronik belge yönetimi ya da Web içerik çözümleri.

2. Ortak kurumsal yazılım ara yüzleri ile bütünleşik çalışan e-belge/doküman yönetim sistemleri: E-doküman ya da e-belge yönetimi sistemleri kapsamında doküman sağlama, doküman yönetimi, belge yönetimi ve çoğunlukla iş süreç yönetimi fonksiyonları olan çözümler bu kapsamdadır. Genellikle orta ya da büyük işletmelerin idari ve yasal koşulları da göz önüne alınarak tüm doküman ve belge yönetimi gereksinimleri çerçevesinde gelişmişlerdir. Genellikle bir ya da birkaç farklı kurumsal yazılım uygulaması ya da Web içerik yönetim yazılımı ile bütünleşik çalışırlar.

3. Kapsayıc KIY çözümleri: İçerik yönetimi kapsamına giren kurum içerisindeki tüm unsurları içerisine alan bütünleşik çözümlerdir. Bu kapsamda doküman, içerik, belge, Web içeriği bilgi sistemleri yönetimi ve ortak yazılım uygulamalarının tümü aynı çözüm içerisinde toplanmıştır (Bailey, 2008; Cimtech Ltd, 2009, s.13).

KIY uygulamalarında verilerin sağlanmasından yayımına kadar olan sürecin aşamaları ise Kampffmeyer (2006) tarafından ayrıntılı biçimde ele alınmıştır. Bu yapıyı şekil 12'de kurumsal içerik yönetimi binası başlığı altında görmek mümkündür. 


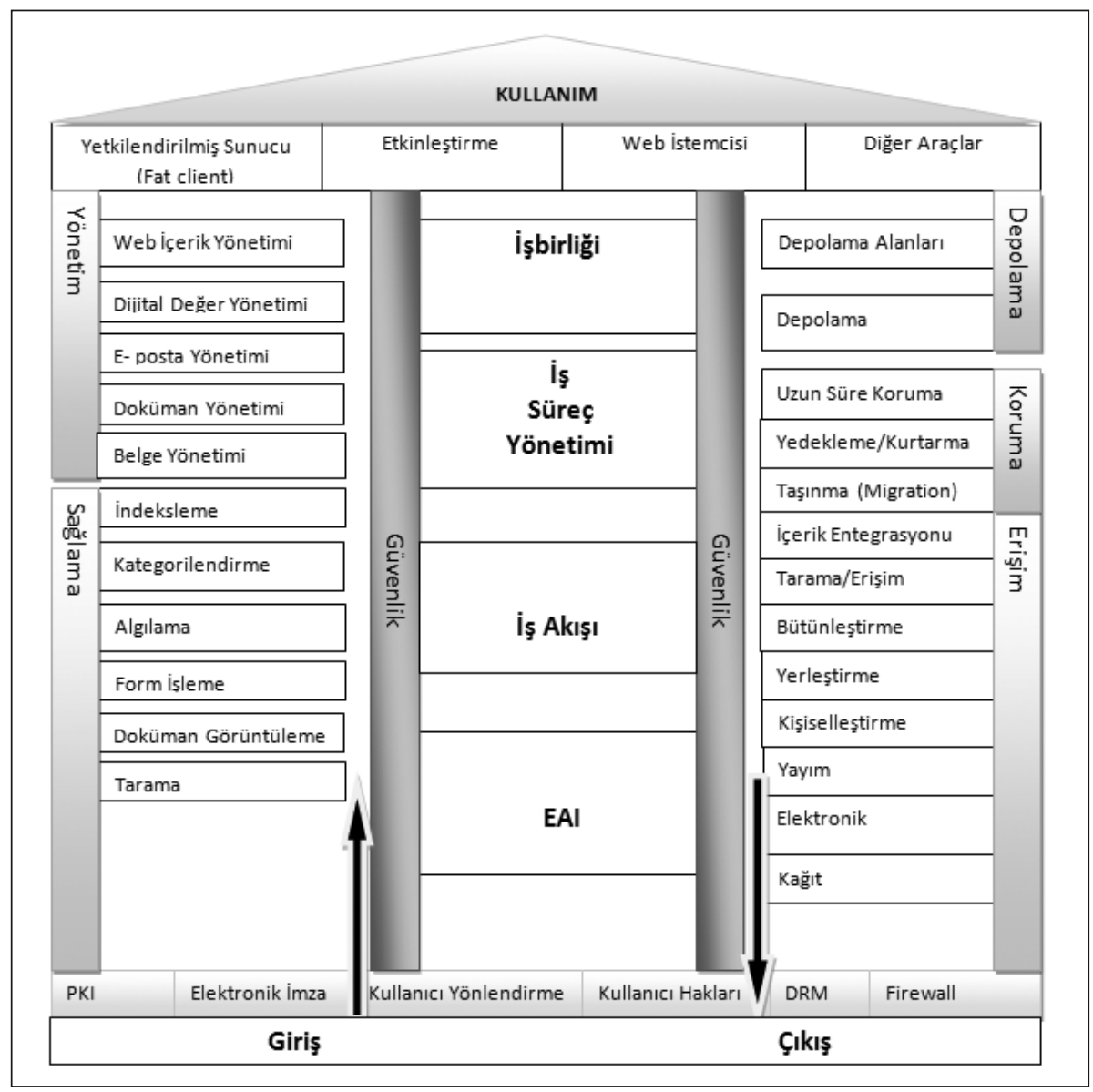

Şekil 12. Kurumsal İçerik Yönetimi Binası (Kampffmeyer, 2006, s.25).

Şekil 12'de görüldüğü gibi KIY, PKI (public/private key infrastructure) ve e-imza gibi güvenlik uygulamaları ile verilerin sisteme aktarılması ve tanımlanmasına dönük sağlama unsurları ile başlamaktadır. Sistem içerisinde veriler farklı içerik yönetimi uygulamalarının parçası olarak idare edilmekte, depolanmakta ve korunmaktadır. KiY içerisinde verilere erişim basılı ya da Web ortamda sağlanabilmektedir. Sistem içerisinde kullanıılar her aşamada yönlendirilme, tanımlanmış sınırlandırmalar ve güvenlik duvarları çerçevesinde gerekli veriye erişmeleri sağlanmaktadır. KiY sistemlerinin dayandığı temel unsurlar arasında farklı içeriğin bütünleştirilmesi, iş akışın sağlanması, iş süreç yönetimi ve verilerin paylaşımını etkileştirmek üzere işbirliği 
koşullarının tanımlanması yer almaktadır. Elektronik sistemlerde verilerin depolanması ve erişimini etkinleştirecek sunucu mimarisinin, Web istemcilerin vb. araçların tasarımı ve etkinleştirilmesi diğer KiY unsurları arasında yer almaktadır.

KIY, elektronik sistemlerde yer alan içeriğin yönetimine çok yönlü bir yaklaşım getirmektedir. Bu çerçevede kurumsal bilgi ve belge yönetimi uygulamaları, aşağıdaki temel başlıklarda verilen alanlarda uygulamaları içerecek biçimde yeniden tanımlanmak durumundadır (Kampffmeyer, 2006, ss. 37-52).

Doküman Yönetimi

$\diamond$ Giriş çıkış kontrolleri (check in/ check out)

$\diamond$ Versiyon yönetimi

$\diamond$ Tarama ve navigasyon

$\diamond$ Görüntüleme (vizualization)

İşbirliği (Collaboration)

$\diamond$ Çoklu ortam kullanarak yaratılan ortak içerik

$\checkmark \quad$ Karar vermeye dönük bilgi

$\diamond \quad$ Elektronik ortamda içeriğin dönük oluşturulan 'whiteboard'lar

$\diamond$ Bilginin bütünleştirilmesi

Web içerik yönetimi

$\diamond$ içerik üretme

$\diamond$ Yayın süreçleri

$\diamond$ Dönüştürme (conversion)

$\diamond$ Güvenlik

$\diamond$ Web sitesi görüntüleme

\section{Belge yönetimi}

$\checkmark$ Dosyalama sistematiği ve kuralları

$\diamond$ Gömü (thesaurus)

$\diamond$ Saklama şemaları

$\diamond$ Metadata

$\diamond$ Arşiv yönetimi

iş akış/iş süreç yönetimi

$\diamond$ Süreç ve yapılandırma yönetimi

$\diamond$ Süreç tasarımı

$\checkmark$ Süreç görüntüleme

$\diamond$ Rotalandırma

$\diamond$ Gözetleme

$\checkmark$ Paralel ve ardışık işleme

$\diamond$ Hatırlatıcı, mühletler

$\diamond$ Kontrol

$\diamond \quad$ Loglama (logging)

\section{Web 2.0 Uygulamalarının KiY Çözümlerine Katkısı}

Web 1.0 uygulamalarının üzerinden 15-20 yıllık bir süre geçtikten sonra İnternet uygulamalarının gelişimine paralel olarak gündeme giren Web 2.0 uygulamaları hızla yayılmaktadır. Web 2.0, Web üzerinde içerik yönetimine dönük bütünüyle yeni modeller sunmaktadır. Bütünleşiksistemlerya da sosyal ağ uygulamaları ile içerikyaratma editoryal bir uygulama olmaktan çıkıp kullanıcı merkezle hale gelmeye başlamıştır. Bu gelişmeler içeriğin ortaklaşa yaratılması ve tekrar kullanımına olanak sağlayan yeni bir yaklaşımı ortaya koymaktadır. Bu kapsamda Web 2.0 şu başlıklar altında tanımlanmaktadır: 
$\diamond$ Platform olarak web

$\diamond$ Ortak aklın harmanlanması

$\diamond$ Veriler işlemcidir

$\diamond$ Yazılım yayıncılığının sonu

$\diamond$ Hafifletilmiş programlama modeli

$\diamond$ Sadece bir aracı üzerinde yazılım uygulamaları (Bailey, 2008; Cimtech Ltd, 2009, s.13).

Van Harmelen (2009) Web 2.0 uygulamalarını 7 farklı türde sınıflamaktadır. Bunlar;

1. Bloglar

2. Wikiler

3. Sosyal imleme-etiketleme (social bookmarking)

4. Medya paylaşım hizmetleri

5. Sosyal ağ sistemleri

6. Ortaklaşa düzenleme (editing) araçları

7. Konsorsiyum ve Duyuru Teknolojileri (Syndication and notification Technologies)

Bu uygulamaların tamamı kullanıcı merkezli olarak içeriği paylaşmak ve yönetmek için çeşitli imkânlar sağlamaktadır. Pasif olarak yayımlanan bir Web içeriğine ek olarak yeni sistemler, içeriğin tekrar kullanımı, gözden geçirilmesi, etiketlenmesi ve ilgili diğer içeriklerle ilişkilendirilmesi olanağı vermektedir. Web 2.0 uygulamalarının kullanımı günümüzde dramatik boyutlara ulaşmıştır. Günümüzde Web 2.0 uygulamaların getirdiği önemli yeniliklerden birisi de Web'i, kişilerin BT alt yapısı haline getirmesi ve istenilen içeriğe erişim ve kullanımda masaüstünü bir aracıya dönüştürmesidir. Bu kapsamıyla Web 2.0 küresel bir içerik yönetim sistemidir. Web 2.0 uygulamaları ortaklaşa üretim, gözden geçirme, yayım, değerlendirme, düzenleme ve arşivleme olanakları ile içeriğin Web ortamında yönetimine dönük tüm gereksinimleri karşılayabilmektedir (Cimtech Ltd, 2009, s.15; Van Harmelen, 2009).

\section{Sonuç}

İş süreç yönetiminin parçası olarak üretilen ve kurumsal bilgi kaynağı olarak yararlanılan belgeler ve belgelerin organizasyonu için tasarlanan sistemler yakın geçmişte hızlı bir değişime uğramıştır. Bu değiş̧im basılı ortamdan elektronik ortama geçişin ötesinde farklı bilgi sistemleri arasındaki yakınsamalar ile yeni yaklaşımların doğmasına yol açmıştır. Bu koşullar, elektronik sistemlerce okunabilir yapılandırılmış bilgiden imaj tabanlı ya da basılı bilgiye kadar farklı ortamlarda, daha önce doküman ve belge yönetimi, idari ve mali bilgi sistemlerin yönetimi ile Web içerik yönetimi kapsamındaki içeriğin KIY uygulamaları çerçevesinde ele alınmasını gerektirmektedir. 
Dile getirilen bu koşulları yaratan temel unsurlardan birini dijitalleştirme oluşturmaktadır. Hâlihazırda dijital ortamda üretilmiş (born digital) (Tonta, 2009, s.757) içerik hızla artmakla birlikte dijitalleştirme pek çok kurumunun öncelikli güncel maddesi arasında yer almaktadır. Kurumsal çerçevede dijitalleştirme gereksinimi duyulan ve geleneksel olarak belge yönetimi kapsamında ele alınan içeriğin dijitalleştirilmesi, tanımlanması ve yönetimi çok yönlü yaklaşımları gerektirmektedir. Öte yandan dijital içeriğin yönetimi geleneksel lineer tanımların ötesinde yeni yaklaşımları gerektirmektedir. Örneğin dijital ortamda belgelerin üretimi ya da sağlanması, düzenlenmesi, dağıtımı, ayıklanması, elektronik sistemlerde bilginin yönetimi ve güvenliği gibi uygulamalar farklı birimlerin uğraşı alanı olmaktan çıkmaya başlamıştır. Yeni ortamlarda sistemin herhangi bir noktasındaki yeni veri girişi, düzenlenmesi, saklama ya da güvenlik koşulların tanımlanması mümkün olabilmektedir.

Değişen koşullar yarattığı fırsatlar yanında güvenlik, yetkilendirme, gizlilik ihlalleri ile uzun süre koruma konularında yarattığı tehditlerle alanda pek çok araştırma ve projenin geliştirilmesini sağlamış, her aşamada eşgüdümlü uygulamalara duyulan gereksinim standartların ortaya çıkışına kaynaklık etmiştir. Yaşanan sorunlara karşın dijital ortamın cazibesi son derece yüksektir. Öte yandan dijitalleştirilecek içeriğin seçimi, metadata tanımlama alanlarının belirlenmesi ve sistem içerisinde etkinliği belirleyen diğer koşulların tanımlanması gerekmektedir. Önemli bir diğer unsur da dijital ortamda bilginin sunumuna dönük ortama karar vermektedir.ilk bakışta öncelikli tercih gibi duran yapılandırılmış formatların temsil kapasitelerinin sınırlılığı daha hibrit çözümleri ön plana çıkarabilmektedir.

Dijital içeriğin artışı ve çeşitlenmesi ile birlikte farklı sistemlerin karşılıklı çalışabilirliği ve bütünleşmesi üzerine geliştirilen olanaklar, kurumlarda geleneksel olarak yürütülen bilgi ve belge yönetimi faaliyetlerini tehdit eden önemli koşullardan biri haline gelmektedir. Bunun nedenlerinden biri yeni ortamlarda bilginin üretimi, sağlanması, düzenlenmesi, yayımı ve değerlendirilmesinin farklı bilgi ve becerileri gerektirmesidir. İçeriğinde kurumun farklı birimlerini ilgilendiren müşteri, personel, idari, mali kayıtlar ile diğer bilgi ve belge kaynakları, Web içeriği ve e-postaların yer aldığı, kişilerin uzmanlık alanlarına ait işlemleri aynı platformda farklı noktalardan yürütebildiği sistemlerin tasarımı, yönetimi, güvenliği ve sürekliliği KiY uygulamaları kapsamında değerlendirilmektedir. Bu uygulamalar kurumsal bilgi, belge ve arşiv yönetimi faaliyetlerini kapsadığına göre yakın gelecekte geleneksel belge yönetimi ve arşiv yaklaşımları ile çözümler üretmek imkânsızlaşacak, bu alanda yetişmiş iş gücü giderek atıl hale gelecek ve marjinalleşecektir. Bu tehditlere karşın, çalışma içerisinde değinilen koşullarda kurumsal bilgi ve belge yönetimi hizmetlerinin yapılandırılması, alanın yönetim bilimleri içerisinde yükselen bir değer olarak yeniden tanımlanmasının yolunu açacaktır. 


\section{Kaynakça}

Asproth, V. (2005). Information technology challenges for long term preservation of electronic information. International Journal of Public Information Systems, 2(1), 27-37.

Azad, A. (2008). Implementing electronic document and record management systems. Boca Raton: Auerbach Publications.

Bailey, S. (2008). Managing the crowd: Rethinking records management for the web 2.0 world. London: Facet Publishing.

Bearman, D. (1994). Electronic evidence: Strategies for managing records in contemporary organizations. Pittsburg: Archives and Museum Informatics.

Bosak, J. ve Brain, T. (1999). XML and the second-generation Web. Scientific American, May, 10 Mart 2010 tarihinde http://www.fhi.rcsed.ac.uk/rbeaumont/virtualclassroom/hig1/scientific american_xml_web_may_1999.pdf adresinden erişildi.

Breuel, T. M. (2005). The future of document imaging in the era of electronic documents. Deptartment of Computer Science University of Kaiserslautern. 30 Eylül 2009 tarihinde http:// pubs.iupr.org/DATA/2005-IUPR-19Jul_1829.pdf adresinden erişildi.

CAMiLEON. (2003). CAMiLEON: Creatieve Archiving at Michigan \& Leeds: emulating the old on the new. 28 Ekim 2009 tarihinde http://www.si.umich.edu/CAMILEON/about/aboutcam.html adresinden erişildi.

CEDARS. (2006). CEDARS: Curl Exemplars in Dijital ARchiveS. 17 Kasım 2009 tarihinde http://www. webarchive.org.uk/wayback/archive/20050111000000/http://www.leeds.ac.uk/cedars/ index.html adresinden erişildi.

Cimtech Ltd. (2009). Managing information and documents: The definitive guide. 1 Eylül 2009 tarihinde http://www.doconsite.co.uk/Resources/PDF/2009/2009_MIDTDG_complete_web. pdf adresinden erişildi.

Cisco, S. L. ve Strong, K. V. (1999). The Value added information chain. Information Management Journal, 33(1), 4-15.

Cornell University Library.(2009). Digital preservation management tutorial. 3 Kasım 2009 tarihinde http://www.library.cornell.edu/iris/tutorial/dpm/terminology/g_resources.html adresinden erişildi.

Dempsey, L. (2006). Libraries and the long tail: some thoughts about libraries in a Network Age. D-Lib Magazine, 12(4).

Duranti, L. (2000). The InterPARES Project: InterPARES Symposium Proceeding, February 2000 - The complete proceedings from the February 2000, InterPARES Symposium. 2 Ekim 2009 tarihinde http://www.interpares.org/display_file.cfm?doc=ip1_symposium_2000.pdf adresinden erişildi.

Duranti, L. (2001). Concepts, principles, and methods for the management of electronic records. The Information Society, 17, 271-279.

Encoded Archival Description. (2002). Encoded Archival Description Document Type Description official site. 22 Haziran 2010 tarihinde http://www.loc.gov/ead/ adresinden erişildi. 
ERA. (2009). ERA: The Electronic Records Archives. United States National Archives and Records Administration web sitesinden 17 Kasım 2009 tarihinde http://www.archives.gov/era/ adresinden erişildi.

Ewers, C. (2007). Basicfunctionalities of a grid-infrastructure for service-oriented content management. Yayımlanmamış yüksek lisans tezi. Hamburg: University of Hamburg.

Herrera-Viedma, E. ve Peis, E. (2003). Evaluating the informative quality of documents in SGML format from judgements by means of fuzzy linguistic techniques based on computing with words. Information Processing and Management, 39, 233-249.

International Council on Archives. (2005). Electronic records. International Council on Archives (ICA) web sitesinden 2 Ekim 2008 tarihinde http://www.ica.org/biblio.php?pdocid=285 adresinden erişildi.

Infotivity Technologies. (2009). Enterprise content management system: RFP - example questions. 16 Eylül 2009 tarihinde http://www.infotivity.com/enterprise-content-management-systemsoftware.html adresinden erişildi.

ISO 15489-1. (2001). International records management standard. Switzerland: ISO/TC 46 Technical Committee:1-11. 17.02.2006 tarihinde http//www.arxiversvalecians.org/document/ISO_TR_ 15489-1.pdf adresinden erişildi.

Kampffmeyer, U. (2004, 3 Mayıs).Trends in document, records and enterprise content management. Keynotepresentation at S.E.R. Conference, Cologna. 26 Şubat 2010 tarihinde http://www.doxtop. com/browse/a21daf8b/trends-in-records-document-and-enterprise-content-management. aspx adresinden erişildi.

Kampffmeyer, U. (2006). ECM-enterprise content management. Project Consult: Hamburg. 9 Kasım 2009 tarihinde http://www.project-consult.net/Files/ECM_White\%20Paper_kff_2006.pdf adresinden erişildi.

Kandur, H. (2007). TS 13298 Elektronik Belge Yönetimi. Kurumlararası Elektronik Doküman Paylaşımı Çalıştayı, 16 Ekim 2007, ODTÜ Kültür ve Kongre Merkezi. 22 Haziran 2010 tarihinde www.srdc.metu.edu.tr/edpcalistayi/TS13298.ppt adresinden erişildi.

Külcü, Ö. ve Külcü, H.U. (2009). Belge yönetiminde program geliştirme: Belge Yönetimi Kapasite Değerlendirme Sistemi. Bilgi Dünyası, 10(2), 261-285.

Lavoie, B. ve Dempsey, L. (2004). Thirteen ways of looking at... digital preservation. 2 Ekim 2008 tarihinde http://www.dlib.org/dlib/july04/lavoie/07lavoie.html adresinden erişildi.

McKemmish, S. (2001). Placing records continuum theory and practice. Archival Science, 1, 333 359.

MINERVA. (2009). MINERVA:Ministerial NEtwoRk for Valorising Activities in digitisation. 17 Kasım 2009 tarihinde http://www.minervaeurope.org/ adresinden erişildi.

Morrison, M., Morrison, J., ve Keys, A. (2002). Integrating web sites and databases. Communications of the ACM, 45(9), 81-86.

Munkvold, B. Erik., Päivärinta, T., Hodne, K. A. ve Stangeland, E. (2006). Contemporary issues of enterprise content management the case of statoil. Scandinavian Journal of Information Systems, 2006, 18( 2), 69-100. 
NEDLIB. (2009). Nedlib: Networked European Deposit Library. 17 Kasım 2009 tarihinde http://nedlib. kb.nl/ adresinden erişildi.

Nordheim, S. ve Päivärinta, T. (2006). Implementing enterprise content management: From evolution through strategy to contradictions out-of-the-box. European Journal of Information Systems, 15, 648-662.

PANDORA. (2008). PANDORA: Preserving and Accessing Networked Documentary Resources of Autralia. 17 Kasım 2009 tarihinde http://pandora.nla.gov.au/ adresinden erişildi.

Päivärinta, T. ve Munkvold, B. E. (2005). Enterprise content management: An integrated perspective on information management. Proceedings of the 38th Hawaii International Conference on System Sciences. 18 Aralık 2009 tarihinde http://ieeexplore.ieee.org/stamp/ stamp.jsp?tp=\&arnumber $=1385431$ adresinden erişildi.

Reed, B. (2000). Electronic records management in transition. 2 Ekim 2008 tarihinde http://www. sims.monash.edu.au/research/rcrg/publications/brep3ert.html adresinden erişildi.

Reference Model for an Open Archival Information System (OAIS). (2002). Consultative comittee for space data system. 26 Şubat 2010 tarihinde http://public.ccsds.org/publications/archive/ 650x0b1.pdf adresinden erişildi.

Rieger, O. Y. (2008). Preservation in the age of large-scale digitization. 5 Ekim 2009 tarihinde http:// www.clir.org/pubs/reports/pub141/pub141.pdf adresinden erişildi.

Runardotter, M. (2007). Information technology, archives and archivists- an interacting trinity for longterm digital preservation. 29 Eylül 2009 tarihinde http://epubl.luth.se/1402-1757/2007/08/LTULIC-0708-SE.pdf adresinden erişildi.

Ruusalepp, R. (2005). Digital preservation in archives: An overview of current research and practices. Talin: Estonian Business Archives.

Scott, J., Globe, A. ve Schiffner, K. (2004). Jungles and gardens: ;The evolution of knowledge management at J.D. Edwards. MIS Quarterly Executive, 3(1), 37-52.

Sellen, A.J. ve Harper, R.H.R. (2001). The Myth of the paperless office. Massachusetts. Michigan: MIT Press.

Smith, H.A. ve McKeen, J.D. (2003). Developments in practice VIII: enterprise content management. Communications of the ACM, 11(33), 647-659.

The Association for Information and Image Management (AIIM). (2009). About AlIM. 18 Aralık 2009 tarihinde http://www.aiim.org/AboutAllM/ECM-ERM-BPM-Association.aspx adresinden erişildi.

The InterPARES Project. (2009). Project overview. 17 Kasım 2009 tarihinde http://www.interpares. org/ adresinden erişildi.

Thomassen, T. (2001). A First introduction to archival science. Archival Science, 1, 373-385.

Tonta, Y. (2009). Dijital yerliler, sosyal ağlar ve kütüphanelerin geleceği. Türk Kütüphaneciliği, 23(4), 742-768

Türk Standartları Enstitüsü. (2007). Bilgi ve dokümantasyon - Elektronik belge yönetimi. (TSE 13298). 1 Kasım 2007 tarihinde http://www.tse.org.tr/Turkish/Abone/Standard_Ara.asp?Dur um=IcsTablosu $\&$ Sira $=1 \&$ EskiKod=01.110 adresinden erişildi. 
Tyrväinen, P. S. ve A., Päivärinta, T. (2002). Introduction to the enterprise content management minitrack. Proceedings of the 36th Hawaii International Conference on System Sciences. IEEE Computer Society. 26 Şubat 2010 tarihinde http://users.jyu.fi/ pttyrvai/Publications/ publications.html adresinden erişildi.

United Nations Archives and Records Management Section. (2006). Guideline on records digitisation. 26 Ekim 2009 tarihinde http://archives.un.org/unarms/en/unrecordsmgmt/ unrecordsresources/guideline\%20on\%20records\%20digitisation.htm adresinden erişildi.

Upward, F. (1998). Structuring the records continuum - part one: postcustodial principles and properties. Archives and Manuscripts, 1996, 24.

Upward, F. (2000). Modelling the continuum as paradigm shift in recordkeepingand archiving processes, and beyond - a personal reflection. Records Management Journal, 10(3), 115-139.

Upward, F. (2004). The Records continuum and the concept of an end product. Archives and Manuscripts, 32 (1), 40-62.

Van Harmelen, M. (2009). Briefing paper on Web 2.0 technologies for content sharing: Web 2.0 an introduction. 2 Eylül 2009 tarihinde http://franklinconsulting.co.uk/LinkedDocuments/Introd uction\%20to\%20Web\%202.doc adresinden erişildi.

VERS. (2009). VERS: Victorian Electronic Records Strategy. 17 Kasım 2009 tarihinde http://www.prov. vic.gov.au/vers/vers/default.asp adresinden erişildi. 


\section{EK: KiY Uygulamalarının Ayrıntıları}

Kurumsal İçerik Yönetimi (Enterprise Content Management, ECM) kurumla ya da kurumsal işlemlerle ilgili içerik ve dokümanların sağlanması (capture), yönetimi (manage), depolanması (store), korunması (preserve) ve erişimi (deliver) üzerine teknolojiler, stratejiler, yöntemler ve araçları kapsamaktadır (AIIM, 2009). Bu kapsamda KIY çalışmalarının unsurları aşağıdaki gibi tanımlanmaktadır (AIIM, 2009; Bandhyopadhya, 2008; Enterprise content management, 2009; Infotivity technologies, 2009; Kampffmeyer, 2004; Kampffmeyer, 2006 ):

\section{Sağlama:}

a. El ile üretilen ya da sağlanan dokümanlar: El ile sağlanan dokümanlar kâğıt dokümanlardan elektron ofis dokümanlarına kadar, e-postalar, formlar, çoklu ortam nesneleri, dijitalleştirilmiş konuşma ve video dosyaları ve mikrofilmleri kapsayan bilginin tüm formlarını içermektedir. Otomatik ya da yarı otomatik sağlama EDI ve XML dokümanları, iş ve ERP uygulamalar ya da var olan uzman uygulama sistemlerindeki kaynakları tanımlamaktadır.

Sağlanan bilgiyi işlemeye dönük teknolojiler: Taranmış dokümanları ve dijital faksları algılamaya dönük teknolojiler.

Bunlar arasında:

Optik Karakter Algılama (Optical Character Recognition, OCR): İmaj bilgilerin makinaca okunabilir karakterlere dönüştürülmesini sağlamaktadır.

El Yazısı Karakter Algılama (Handprint Character Recognition, HCR): El yazısı ile yazılmış ya da çizilmiş bilgilerin makinaca okunabilir hale dönüştürülmesini sağlamaktadır. Konu ile ilgili gelişmeler devam etmektedir.

Akıllı Karakter Algılama (Intelligent Character Recognition, ICR): OCR ve HCR teknolojilerinin bir ileri aşamasını oluşturmaktadır. Sonuçları geliştirmek için karşılaştırma, mantıki bağlantılar ve kontroller yapılmakta, referans listeleri ve var olan master veriler karşılaştırılmaktadır.

Optik İ Algılama (Optical Mark Recognation, OMR): OMR kontrol kutuları için kullanılmaktadır. Örneğin anket vb formlarda işaretlenmiş verilerin algılanmasıdır.

Barkod: Barkodlanmış dokümanlar otomatik algılama ve dosyalamada kullanılmaktadır.

b. Doküman görüntüleme: Doküman görüntüleme işleme teknikleri imajların sağlanması, görüntüleme kalitesinin geliştirilmesi için kullanılmaktadır. Görüntü 
formunun değiştirtmesi, hizalama, açıklama, yakınlaştırma, sayfaların ayrılması, netleştirme gibi uygulamaları içermektedir.

c. Form işleme: Formların sağlanmasında bilgi içeriği ve doküman karakterleri belirleyici olsa da iki grup teknolojiden söz edilmektedir.

Kâğıt formlar: Daha önce kağıt ortamda yer alan kurumsal ya da kişisel formların taranarak ve algılama teknolojileri kullanılarak elektronik ortamda kullanılmasının sağlanmasıdır.

E-formlar/Web formları: Otomatik sistemlerce şablon yapısı ve diğer özellikleri bozulmadan elektronik formların sağlanmasıdır.

d. COLD (Computer Output to Laser Disc): Kurumsal Rapor Yönetimi (Enterprise Report Management) olarak da bilinmektedir. Muhasebe kayıtları, envanterler, gelen ve giden belgeler gibi yüksek volümlerdeki bilgi ve belge kaynaklarının sağlanması, arşivlenmesi, depolanması ve erişimi için kullanılmaktadır. Bu sistemler basılı sistemler ya da mikrofiş uygularların yerine uygulanmaktadır. COLD terimi, Uluslararası Standartlar Örgütü (ISO), Amerikan Ulusal Standartlar Örgütü (ANSI) ve konuyla ilgili çalışmalara öncülük eden Bilgi ve İmaj Yönetimi Derneği (AlIM) tarafından Kurumsal Rapor Yönetimi terimi ile eş anlamlı olarak kullanılmaktadır (Enterprise Content Management, 2010).

e. Bütünleştirme (Aggregation): Farklı üretim ve sağlama araçlarından elde edilen verilerin birleştirilmesi işlemidir. Amaç farklı kaynaklardan gelen verilerin tek biçime dönüştürülmesi ya da ortak bir sistem içerisinde kullanılabilmesinin sağlanmasıdır.

Yönetim: Bilginin yönetimi, işlenmesi ve kullanımı için gerekli fonksiyonların tanımlanması, yönetim ve erişim için veri tabanları ile yetkilendirme sistemine erişim uygulamalarını içerir.

KiY sistemlerinin amacı alt sistemleri oluşturan doküman yönetimi, Web içerik yönetimi, belge yönetimi ve iş akışı yönetimi uygulamalarına dönük bütünleşik yapının etkin yönetimine dönük uygulamaların geliştirilmesidir. Bu kapsamda standart ara yüzlerin oluşturulmuş ve güvenli iletişim işlemlerinin tanımlanmış olması gerekmektedir.

Işbirliği (collaboration) - Ortak Sistemler ve Grup Yazılımları (groupware): Iş̧birliği genel bir tanımla ortak çalışmak anlamına gelmektedir. Özellikle geliştirilen grup yazılımları içeriği oluşturan farklı kaynakları arasında işbirliğini son derece etkin hale getirmektedir. Özellikle;

$\diamond \quad$ Ortak olarak kullanılabilen bilgi veri tabanları

$\diamond$ Bütünleşik, eşzamanlı kontrolü bilgi işleme 
$\diamond \quad$ Ortak bilgi işleme için yetenekler, kaynaklar ve geçmiş̧e dayanan bilgi

$\diamond$ İdari unsurlar. Örneğin beyin fırtınası için beyaz tahta, randevu takvimi, proje yönetimi gibi.

$\diamond \quad$ Video konferans gibi iletişim uygulamaları

$\diamond \quad$ Ortak bilgi işleme için diğer uygulamalardaki bilginin bütünleştirilmesi.

Web İçerik Yönetimi: KIY, web içerik yönetimi ile bütünleşmek durumundadır. Ancak kurumun internet, extranet ya da ilgili bir portalda yayımlamayı düşündüğü bilgi içeriğini önceden tanımlaması, kimlerin hangi yetkiyle ilgili içeriğe erişimin sağlanacağının belirlenmesi gerekir. Web içerik yönetimi aşağıdaki fonksiyonları içerir:

$\diamond$ Kontrollü üretim ve yayım sürecinde var olan bilginin düzenlenmesi ya da üretimi,

$\diamond$ Web sunumu için bilginin sağlanması ve idaresi,

$\diamond$ Çeşitli gösterim formatlarının, kişiselleştirilmiş gösterimlerin ve versiyonların otomatik olarak dönüştürülmesi,

$\diamond$ Kamuya açık ve kapalı bilginin yayımı ve erişimi ilkelerinin belirlenmesi,

$\diamond$ İnternet sunumlarının görüntülenmesi (tarayıcı, HTML, XML vb.).

Pek çok kurum Web içerik yönetimini KiY uygulamalarının bir parçası olarak düşünmemektedir. Ancak kurumsal içeriğin elektronik ortamda tanımlanması, depolanması ver erişim koşullarının belirlenmesi Web içerik yönetimi uygulamaları ile birlikte yürütülmek durumundadır.

Belge Yönetimi-Dosya ve Arşiv Yönetimi: Geleneksel elektronik arşiv sistemlerinin ötesinde, belge yönetimi (bu kapsamda elektronik belge yönetimi ya da ERM uygulamaları) kurumun arşivleme gereksinimi duyduğu belge, önemli bilgi ve verilerin yönetimi içermektedir. Belge yönetimi depolama ortamlarına bakılmaksızın belge niteliğindeki tüm dokümanların yönetimini kendi kapsama alanına alarak aşağıdaki işlevler altında tanımlanmaktadır:

$\diamond$ Bilginin düzenli biçimde depolanması için dosya planı ve diğer yapılandırılmış indekslerin görüntülenmesi,

$\diamond$ Thesarus ve kontrollü listelerle destekleyerek bilginin anlaşılır biçimde indekslenmesi,

$\diamond$ Belge saklama ve imha şemalarının yönetimi,

$\diamond \quad$ Bilgi formatı ve içeriğinin korunması,

$\diamond$ Bilginin dağıtımı, depolanması ve erişimi üzerine genel ve kuruma özel koşulların tanımlanması ve uygun sistemlerin geliştirtmesi. 
iş akışı / Iş̧ Akış Süreç Yönetimi: iş̧ akışı ve iş akış süreç yönetimini birbirinden ayrı tanımlamak gerekmektedir. İş akışı iş sürecinin kontrolü için geliştirilen teknik ve uygulamalardan oluşmaktadır. Iş akışı bir takım uygulamaları ve araçları da gerektirmektedir. Bu uygulamalar ve araçlar;

$\diamond$ işs süreçlerinin ve organizasyon yapısının tanımlanması,

$\diamond$ İlgili doküman ve veriler ile gruplandırılmış bilginin sağlanması, idaresi, tanımlanması ve iletimi,

$\diamond$ Veri işleme ve ofis uygulamaları ile ortaklaşa çalışma,

$\diamond$ Hatırlatıcı, yetkilendirici, mühletler (deadlines) ve diğer idari fonksiyonlar

$\diamond$ Işs sürecinin statüsü, dolaşımı ve çıktılarının kontrolü ve dokümantasyonu,

$\diamond$ Tasarım ve gösterim işlemlerine dönük araçlardır.

Iş akış süreç yönetimi iş akışından bir adım ötedeki uygulamaları tanımlamaktadır. Yukarıdaki uygulama ve araçların kurumsal içerik yönetimi kapsamında bütünleşik yürütüldüğü uygulamalar iş akış süreç yönetimi kapsamında değerlendirilmektedir. Bu kapsamda:

$\diamond$ Fonksiyonları önceden tanımlanmış bütüncül bir iş akış sistemi,

$\diamond$ Sunucu düzeyinde işlem ve veri kontrolü,

$\diamond \quad$ Farklı uygulamalar arasında entegrasyonu sağlamaya dönük kurumsal uygulama entegrasyonu (enterprise application integratin, EAl)

$\diamond$ Yapılandırılmışkurallar, bilgiambarlarınınentegrasyonu, kullanıcılarıçalışmalarında destekleyen uygulamalarla iş bilgi sistemi (business intelligence, $\mathrm{BI}$ ).

Depolama: Depolama geçici, belirli bir süre ve akılcı olmak üzere üç aşamada tanımlanmaktadır. Bu çerçevede her aşamada verilerin hangi ortamlarda kimlerin erişimine açı tutulacağı, koruma ve güvenlikle ilgili uygulamaların ne şekilde tanımlanacağının belirlenmesi gerekmektedir. Depolamada aşağıdaki unsurlar ön plana çıkmaktadır.

Dosyalama Sistemi: Dosyalama sistemi birbiriyle ilişkili bilgilerin bir arada ve kurumsal ilişkilerini yansıtacak biçimde depolanması ve erişimi ile ilgilidir. Kurumun gerek kendi birimleri arasında gerekse ilişkili diğer kurumlarla iletişiminde standart dosya planlarının uygulanması son derece önemlidir.

İçerik Yönetim Sistemi: Özel depolama sistemlerine ve veri tabanlarına içeriğin kaydedilmesi ve erişimine dönük uygulamaları kapsamaktadır.

Veri tabanları: Veri tabanı idareci erişim bilgisi. Ayrıca dokümanların, içeriğin ya da medya varlıklarının doğrudan kaydedilmesini de içerir. 
Veri Ambarı (data warehouse): Veri tabanlarını temel alan ancak veri tabanlarına göre daha karmaşık yapıdaki depolama sistemleridir. Bilgi kaynaklarından bilgi sağlar ya da gönderme yaparlar.

Koruma: Koruma unsurları arasında, kurumsal içeriğin uzun süre korunması, güveli depolama ve yedekleme, değiştirilmemiş bilgi ve arşivsel değeri olmayan kısa dönemli bilginin etkin denetimi yer almaktadır. Literatürde ilgili çalışmalar elektronik arşivleme olarak da tanımlanmaktadır. Bu kapsamda belge yönetimi, doküman ya da imaj yönetimi, bilgi erişim ve depolama sistemleri de yer almaktadır. Koruma faaliyetlerinde uzun süre koruma (long term preservation) ayrı bir önemle ele alınmak durumundadır. Elektronik sistemlerde bilginin depolanabilme süresi ve alternatif yedekleme uygulamaları üzerinde durulması gereken konular arasındadır. Bu kapsamda aşağıdaki depolama ortamları üzerinde durulmalıdır.

$\diamond$ WORM optik diskleri (Write Once Read Many, WORM),

$\diamond$ WORM hard disk sürücüleri Özel yazılım koruması ile üzerinde yazım, silinme, düzeltme vb işlemlerinden koruyan manyetik disk depoları,

$\diamond$ Depolama Ağları,

$\diamond$ Mikrofilmler,

$\diamond$ Kâğıt.

Arayüz, metadata, veri yapıları ve obje formalarındaki standartlar da bilgiye güvenli biçimde erişmek için önemlidir. Uzun süre koruma uygulamalarında ayrıca iki unsur önem kazanmaktadır.

Taşınma (migration): İçeriğin taşınmasında süreklilik, indek verileri ve meta verileri, eski sistemden yeni sisteme objelerin özgün biçimde transferi, erişim ve kullanım güvenlik tanılamaları, ilgili olmayan içeriğin silinmesi, depolanmış içeriğin formatlarının güncellenmesi üzerine yakınsama (conversion) teknolojiler bu kapsamda değerlendirilmektedir.

Emülasyon (emulation): Eski yazılımların emülasyonu orijinal veri ve objelere erişim için gereklidir. Özel yazılım olanakları ile de geçmiş sürümlerde hazırlanmış içeriklere yeni yazılımlarda erişmek mümkün olabilmektedir.

Erişim: Erişim, temel KIY parçalarından olan yönetim, depolama ve koruma unsurlarında bilginin sunumu ile ilgilidir. Erişim çalışmaları kapsamında sağlanacak bilginin hangi formatlara aktarılacağı, dönüşüm ve güvenlik teknolojileri ile yayım ile ilgili ilkeler bu kapsamda değerlendirilmektedir. Şablon ve formatlama çıtılarına dönük araçlar, yayım ve yayıncılık uygulamaları erişimin unsurlar arasındadır. 
Dönüşüm (transformation) tekolojileri arasında aşağıdakiler sıralanabilir:

$\diamond$ COLD/ERM (Computer Output to Laser Disk).

$\diamond$ Elektronik ortamda bilginin çıktılarının yayımı ç̧in kullanııı.

$\diamond$ Kişiselleştirme.

$\diamond$ Web tabanlı postalların bir özelliği olmakla birlikte ECM uygulamalarına da uyarlanabilir. Kişiselleştirme uygulamaları kullanıcılara belirli fonksiyonları ve gereksinim olan bilgiyi kullanabilme olanağı verir.

$\diamond \quad$ XML (Extensible Markup Language).

$\diamond$ Arayüzlerin, yapıların, metadata bilgilerinin ve dokümanların tanımlanmasına olanak veren bir tanımlama dilidir. XML bilginin tanımlanması üzerine evrensel bir teknolojiye dönüşmüştür.

$\diamond$ PDF (Portable Document Format).

$\checkmark$ Platformdan bağımsız olarak bilginin sunumuna olanak tanıyan basım ve yayım formatıdır. TIFF'den ayrı olarak PDF içerik taramasına, metadata eklemesine ve elektronik imza uygulamalarına olanak sağlamaktadır.

$\diamond \quad$ XPS (XML Kâğıt Spesifikasyonu).

$\diamond$ XPS dokümanlarının dağıtımı, arşivlenmesi, gönderimi tanımlayan Microsoft tarafından geliştirilmiş bir XML spesifikasyonudur.

$\diamond$ Dönüştürücü ve görüntüleyiciler.

$\diamond$ Tekbiçim formatlara dönüştürülmesi için bilginin yeniden formatlanması ile farklı formatlardaki bilginin çıktısı ve gösterimi.

$\diamond$ Sıkıştırma.

$\diamond$ Bilginin kapladığı alanı daraltmak için kullanılan uygulamalar.

$\diamond$ Birlik (syndication).

$\diamond$ Birlik yönetimi kapsamında farklı formatlardaki içeriğin gösterimi için kullanılır. Aynı içeriğin farklı formlarda, farklı amaçlarla çoklu kullanımına izin veririr.

Güvenlik Teknolojileri: KiY uygulamalarında güvenlik teknolojilerinin her aşamada tanımlanması gerekir. Örneğin elektronik imza sadece doküman gönderilirken değil, veriler örneğin taranarak sağlanırken, doküman bütünlüğünün korunarak alındığını ortaya koyma için, kullanıır. Kısa adı PKI (public/private key infrastructure) olan anahtar tanımlama alt yapıları elektronik imza için temel teknolojilerdir. PKI'ler anahtar ve sertifikasyonlar ile imzaların özgünlüğünü denetlerler. Diğer elektronik imza uygulamaları göndericiyi ve gönderilen verinin bütünlüğünün korunduğunu tanımlarlar. Avrupa'da farklı güvenlik koşulları tanımlanış basit (simple), gelişmiş (advanced) ve yetkilendirilmiş (qualified) olmak üzere üç farklı elektronik imza formatı kullanılmaktadır. Pek çok $A B$ ülkesinde yetkilendirilmiş elektronik imza uygulamaları 
senet hükmünde kabul edilmektedir. Güvenlik teknolojileri kapsamında dijital hak yönetimi (dijital right management, DRM) ve filigran (watermarking) uygulamaları da yer almaktadır.

Yayım: KiY uygulamalarına ilişkin teknolojiler temel olarak, kontrolü ya da kullanıcı oryantlı biçimde çeşitli rotalardan hedef kitleye KIY içeriğinin sağlanmasına odaklanmaktadır. Kullanıcılar ilgili içeriği e-postalar, veri medyaları, duyurular (memos), portallardan ve Web sitelerinden pasif yayım ile sağlayabilmektedirler. Olası çıktı ve yayım araçlar arasında;

$\diamond$ İnternet, extranet ve intranet,

$\diamond \quad$ E- iş portalları,

$\diamond$ Çalışan portalları,

$\diamond$ E-posta ve faks,

$\diamond \quad E D I, X M L$ ve diğer formatlardan veri transferi,

$\diamond \quad$ Cep telefonu, PDA ve diğer mobil araçlar,

$\diamond$ Dijital TV ve diğer çoklu ortam hizmetleri,

$\diamond \quad$ CD, DVD ve taşınabilir bellek araçları ve

$\diamond$ Kâğıt yer almaktadır. 